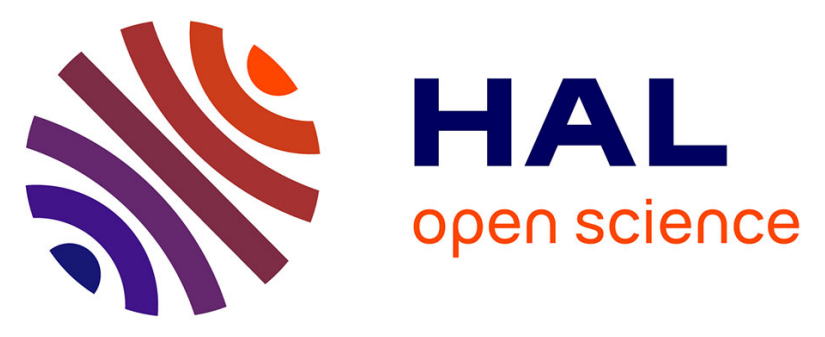

\title{
Deflection of natural oil droplets through the water column in deep-water environments: The case of the Lower Congo Basin
}

Romain Jatiault, Damien Dhont, Lies Loncke, Xavier Durrieu de Madron, Dominique Dubucq, Claire Channelliere, François Bourrin

\section{To cite this version:}

Romain Jatiault, Damien Dhont, Lies Loncke, Xavier Durrieu de Madron, Dominique Dubucq, et al.. Deflection of natural oil droplets through the water column in deep-water environments: The case of the Lower Congo Basin. Deep Sea Research Part I: Oceanographic Research Papers, 2018, 136, pp.44 - 61. 10.1016/j.dsr.2018.04.009 . hal-01930762

\section{HAL Id: hal-01930762 \\ https://hal-univ-perp.archives-ouvertes.fr/hal-01930762}

Submitted on 22 Oct 2019

HAL is a multi-disciplinary open access archive for the deposit and dissemination of scientific research documents, whether they are published or not. The documents may come from teaching and research institutions in France or abroad, or from public or private research centers.
L'archive ouverte pluridisciplinaire HAL, est destinée au dépôt et à la diffusion de documents scientifiques de niveau recherche, publiés ou non, émanant des établissements d'enseignement et de recherche français ou étrangers, des laboratoires publics ou privés. 


\title{
Deflection of natural oil droplets through the water column in deep-water environments: The case of the Lower Congo Basin
}

\author{
Romain Jatiault ${ }^{\mathrm{a}, \mathrm{b}, *}$, Damien Dhont ${ }^{\mathrm{a}}$, Lies Loncke ${ }^{\mathrm{b}}$, Xavier Durrieu de Madron ${ }^{\mathrm{b}}$, \\ Dominique Dubucq $^{\mathrm{a}}$, Claire Channelliere ${ }^{\mathrm{c}}$, François Bourrin ${ }^{\mathrm{b}}$ \\ a Total SA, Centre Scientifique et Technique Jean Feger (CSTJF), Avenue Larribau, 64018 Pau, France \\ ${ }^{\mathrm{b}}$ University of Perpignan Via Domitia, Centre de Formation et de Recherche sur les Environnements Méditerranéens (CEFREM), UMR 5110, 52 Avenue Paul Alduy, 66100 \\ Perpignan, France \\ ${ }^{\mathrm{c}}$ Total SA, Tour Coupole, 2 place Jean Miller, La Défense 6, 92400 Courbevoie, France
}

\section{A R T I C L E I N F O}

\section{Keywords:}

Hydrocarbon seepage

Oil slick

Lower Congo Basin

Underwater deflection

Deep-water Pockmark

Ascension velocity

\begin{abstract}
A B S T R A C T
Numerous recurrent seep sites were identified in the deep-water environment of the Lower Congo Basin from the analysis of an extensive dataset of satellite-based synthetic-aperture radar images. The integration of current data was used to link natural oil slicks with active seep-related seafloor features. Acoustic Doppler current profiler measurements across the water column provided an efficient means to evaluate the horizontal deflection of oil droplets rising through the water column. Eulerian propagation model based on a range of potential ascension velocities helped to approximate the path for rising oil plume through the water column using two complementary methods. The first method consisted in simulating the reversed trajectory of oil droplets between sea-surface oil slick locations observed during current measurements and seep-related seafloor features while considering a range of ascension velocities. The second method compared the spatial spreading of natural oil slicks from 21 years of satellite monitoring observations for water depths ranging from 1200 to $2700 \mathrm{~m}$ against the modeled deflections during the current measurement period. The mapped oil slick origins are restricted to a $2.5 \mathrm{~km}$ radius circle from associated seep-related seafloor features. The two methods converge towards a range of ascension velocities for oil droplets through the water column, estimated between 3 and $8 \mathrm{~cm} \mathrm{~s}^{-1}$. The low deflection values validate that the sub-vertical projection of the average surface area of oil slicks at the sea surface can be used to identify the origin of expelled hydrocarbon from the seafloor, which expresses as specific seafloor disturbances (i.e. pockmarks or mounds) known to expel fluids.
\end{abstract}

\section{Introduction}

Natural hydrocarbon seeps occur along most continental margins (Wilson et al., 1973; Levy and Ehrhardt, 1981; MacLean et al., 1981; Becker and Manen, 1988; Kvenvolden and Cooper, 2003; Zatyagalova et al., 2007; Jauer and Budkewitsch, 2010; Körber et al., 2014; Suresh, 2015; Jatiault et al., 2017).

For environmental purposes, understanding the dynamic behavior of the oil plume is crucial for emergency response to oil spills (Spaulding, 1988; Reed et al., 1999; Price et al., 2006; Leifer et al., 2006, 2012; Chen et al., 2007; MacFadyen et al., 2011; Fingas and Brown, 2014; MacDonald et al., 2015). Defining the rise path of the oil helps to target probable areas affected by environmental damage due to anthropogenic spills (Chen et al., 2015; Korotenko, 2016). For scientific expeditions and exploration campaigns, understanding the rise paths of the oil plume is of prime importance to link sea surface natural oil slicks to their origin on the seafloor (Crooke et al., 2014). The targeting and inventorying of seafloor areas accommodated by deep-sea communities is facilitated by identifying seepage areas (MacDonald et al., 1996; Garcia-Pineda et al., 2010; Lessard-Pilon et al., 2010; Jones et al., 2014). In petroleum exploration, the identification of seafloor seeps is used as a first-order tool to identify active petroleum systems and confirms the presence of matured source rocks (e.g. Abrams, 2005). Combined with geophysical sub-seafloor datasets, locating active seafloor thermogenic seeps provides significant evidence for understanding the hydrocarbon plumbing system (Serié et al., 2016). Pockmarks, which are local depressions on the seafloor associated with contemporary focused fluid flow (e.g. King and MacLean, 1970; Hovland and Judd, 1988), are widely recognized as the seafloor outlet of expelled fluids. Even if hydrocarbon migration across the water

\footnotetext{
* Corresponding author at: University of Perpignan Via Domitia, Centre de Formation et de Recherche sur les Environnements Méditerranéens (CEFREM), UMR 5110, 52 Avenue Paul Alduy, 66100 Perpignan, France.

E-mail addresses: romain.jatiault@gmail.com, romain.jatiault@univ-perp.fr (R. Jatiault).
} 
Table 1

Compilation of reported values of hydrocarbon ascension velocities through the water column.

\begin{tabular}{|c|c|c|c|c|}
\hline Reference & Hydrocarbon type & Minimum value $\left(\mathrm{cm} \mathrm{s}^{-1}\right)$ & Maximum value $\left(\mathrm{cm} \mathrm{s}^{-1}\right)$ & Type of study \\
\hline Rehder et al. (2002) & Methane & 26 & 27 & Laboratory \\
\hline Leifer and Patro (2002) & Methane & 5 & 15 & Laboratory \\
\hline Greinert et al. (2006) & Methane & 12 & 22 & In-situ measurement (Black Sea) \\
\hline De Moustier et al. (2013) & Methane & 17 & 23 & In-situ measurement (Gulf of Mexico) \\
\hline Leifer and MacDonald (2003) & Methane, oily bubbles & 2 & 20 & Laboratory \\
\hline Crooke et al. (2015) & Oil and gas mixture & 5 & 50 & In-situ measurement (Gulf of Mexico) \\
\hline Van Ganse et al. (2013) & Oil and gas mixture & 2 & 18 & Laboratory \\
\hline Körber et al. (2014) & Oil and gas mixture & 13 & 15 & In-situ measurements (Black Sea) \\
\hline
\end{tabular}

column presents strong and varied implications, the phenomenon remains strongly under-evaluated.

The fate of oil droplets either sinking to the seafloor or rising through the water column depends on the buoyancy of the expelled hydrocarbons. Lighter components rise through the water column (De Beukelear et al., 2003; Körber et al., 2014; Garcia-Pineda et al., 2015) until reaching the sea surface (e.g. MacDonald et al., 2002; Greinert et al., 2006; Rollet et al., 2006; Smith et al., 2014).

During the ascent through the water column, oceanic currents affect the deflection of the plume by advecting the oil droplets during their rise from the seafloor to the surface (Crooke et al., 2015). The lateral deflection distance is controlled by the current strength and the transit time of the oil droplets in the water column. The transit time is controlled by both the water depth and the ascension velocity and can be affected by horizontal and vertical turbulent dispersion. Estimating the ascension velocity is therefore compulsory for quantifying the range of the deflection (Table 1).

The few case studies documenting the ascension velocity of oil droplets are exclusively based on laboratory experiments or measured in a few marine settings (e.g. Gulf of Mexico and Black Sea). The reported ascension velocities range from 2 to $50 \mathrm{~cm} \mathrm{~s}^{-1}$. While most studies focused on the vertical ascent of oil droplets in the water column (MacDonald et al., 2002; Greinert et al., 2006; Crooke et al., 2015; Chen et al., 2015; Korotenko, 2016), only a handful have addressed the horizontal deflection associated with currents in natural systems. In the Gulf of Mexico, the lateral deflection of oil droplets was estimated using an affine deflection function based on water depths (Garcia-Pineda et al., 2010).

Quantitative models approximate the ascension velocity of hydrocarbon droplets based on characteristics such as bubble shape and diameter (Clift et al., 1978; Perry and Green, 1984; Korotenko, 2016). Depending on the oil type and environmental conditions, the shape of the oil droplets can range from spherical, ellipsoidal to "jellyfish" (Van Ganse et al., 2013; Aprin et al., 2015). The droplet size distribution and rising regime depend on the oil type (Clift et al., 1978); however, oil composition is in most case unknown due to unavailable in-situ samplings. In addition, the composition and properties of expelled oil from natural seeps can be altered by external factors including biodegradation ( Head et al., 2003; Larter et al., 2003; Larter et al., 2006; Jones et al., 2008; Peters et al., 2007; Aeppli et al., 2014) and gas hydrate formation (Rehder et al., 2002; Leifer and MacDonald, 2003; McGinnis et al., 2006).

This paper aims to link sea-surface oil slicks to seep-related seafloor features by estimating the horizontal deflection of oil droplets, based on the integration of current measurements, satellite-based surface slick data, and high-resolution bathymetric maps. In addition, our objective is to quantify the temporal variability of the oil plume deflection offset through the water column. Indeed, affine deflection functions still need to be validated in open-sea conditions that are usually associated with a greater hydrodynamic complexity. Understanding the rise path of oil in a challenging area will definitely contribute to understand the probable deflection ranges of oil in other provinces.

\section{Regional settings}

The study area is located offshore Angola in the Lower Congo Basin (LCB) (Fig. 1), in water depths ranging from 1200 to $2700 \mathrm{~m}$. The LCB deep-water province corresponds to one of the most important natural oil seep systems in the world, where $4380 \mathrm{~m}^{3}$ of oil is expelled each year towards the sea surface (Jatiault et al., 2017). In addition, extensive oil and gas exploration activities in the LCB during the last decades have provided a large volume of geophysical data, both at the seafloor and in the water column. The LCB appears to be a key area for understanding the dynamic behavior of oil droplets rising through the water column.

The significant occurrence of oil seeps in the LCB is mainly associated to the presence of prolific source rocks intervals including to the pre-salt Early Cretaceous Bucomazi Fm (Burwood, 1999; Cole et al., 2000) and the post-salt Late Cretaceous Iabe Fm, (Cole et al., 2000; Schoellkopf and Patterson, 2000; Séranne and Anka, 2005). An efficient plumbing system is reported in deep province (Andresen and Huuse, 2011; Andresen, 2012, Gay et al., 2007) in association with strong compressive salt tectonics (Fig. 1; Marton et al., 2000; Brun and Fort, 2004; Fort et al., 2004; Séranne and Anka, 2005; Guiraud et al., 2010).

The LCB presents open-sea oceanic conditions characterized by a complex vertical succession of surface and deep currents (Peterson and Stramma, 1991; Schneider et al., 1996; Holmes et al., 1997; Stramma and England, 1999; Shannon, 2001; Hardman-Mountford et al., 2003; Hopkins et al., 2013; Phillipson and Toumi, 2017). The main currents in the LCB reported in the literature are shown in Fig. 1. The major surface current following along the coast is the Angolan Current (AC) transporting equatorial waters from 0 to roughly $300 \mathrm{~m}$ below the sea surface (Moroshkin et al., 1970; Hardman-Mountford et al., 2003). The AC is steady, narrow, and fast current flowing southwards with velocities ranging from 20 to $50 \mathrm{~cm} \mathrm{~s}^{-1}$, and salinities around 36.4 (Moroshkin et al., 1970; Hardman-Mountford et al., 2003). The northernmost branch of the Benguela Coastal Current (BCC) is reported to bypass the border with the AC at the Angolan Benguela Frontal Zone (ABFZ), bringing cold and low salinity waters along the Angolan coast (Schneider et al., 1996; Hopkins et al., 2013). The influence depth of the BCC is limited to the surface and subsurface layers. The southwardflowing Southern Intermediate Counter Current (SICC), transporting Antarctic Intermediate Water (AAIW) (Stramma and England, 1999; Stramma and Schott, 1999; Shannon, 2001), controls intermediate water circulation $(500-1000 \mathrm{~m})$. The deep-water circulation along the Angolan coast corresponds to the slow southward flow of the North Atlantic Deep Water (NADW) (Lynn, 1971; Stramma and England, 1999; Arhan et al., 2003). This bottom boundary current could correspond to the eastern retroflection of the Deep Western Boundary Current (DWBC) (Garzoli et al., 2015).

\section{Data and methods}

\subsection{Data}

\subsubsection{Mooring measurements}

Currents were measured with $\mathrm{RD}^{\circledast}$ instruments Acoustic Doppler 


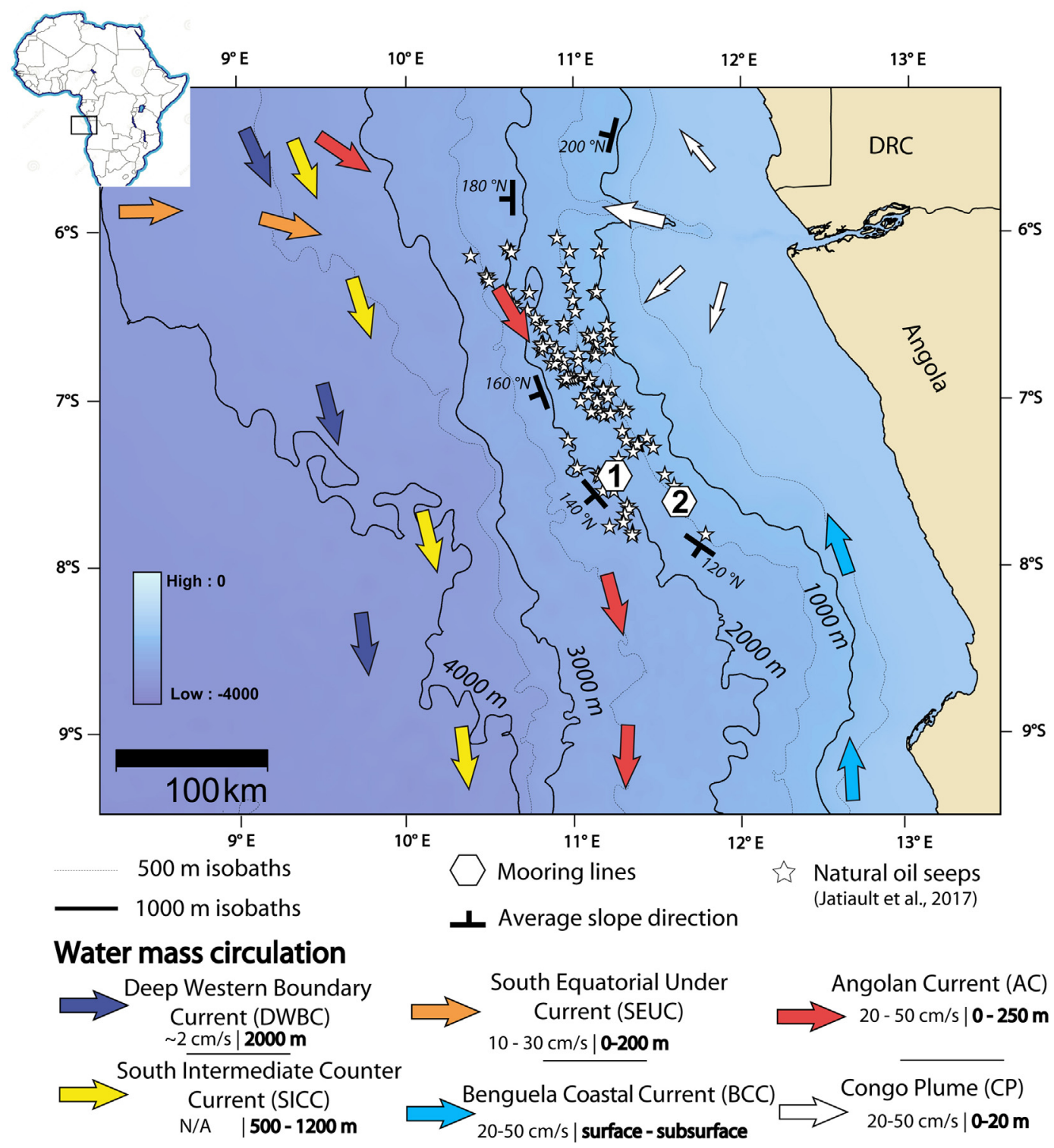

Fig. 1. Location map of the study area and characteristics of the reported main currents (depth and current speed range). The radial variation of the average slope direction of the seafloor is associated with the alluvial cone of the Neogene Congo deep-sea fan.

Current Profilers (ADCP - Rowe and Young, 1979; Gordon and Instruments, 1996) and Aanderaa Seaguard single-point Doppler Current Sensors (DCS) mounted on two different moorings (Table 2, see location on Fig. 1). The upper and sub-surface layers were sampled with upward-looking $300 \mathrm{kHz}$ and $75 \mathrm{kHz}$ ADCPs, respectively. The deeper layers were sampled with single-point DCS positioned every $200-250 \mathrm{~m}$ down to the bottom. The observation period lasted 6 months (Jan. 16, 2009 - Jul. 26, 2009) for mooring 1, and 13 months (Sept. 22, 1997 Oct. 27, 1998) for mooring 2 . The data were corrected considering a magnetic declination of $5.4^{\circ} \mathrm{E}$ between the geographic and magnetic poles.

Mooring 1 was located close to recurrent oil seep sites, which is a considerable advantage for understanding the plume dynamic deflection by integrating both mooring records and satellite images (Fig. 2). Measurements were restricted to a 6-month period, and indeed limiting the concomitant availability of satellite images and the assessment of the effect of the seasonal variability of the current. Mooring 2 was located further south from the main oil seepage area (Fig. 2) limiting the integration with satellite image; however, the thirteen month monitoring period was relevant in assessing the seasonal variability of the

Table 2

Characteristic of ADCP records for mooring 1 and mooring 2.

\begin{tabular}{|c|c|c|c|c|c|c|c|}
\hline Mooring Point & $\begin{array}{l}\text { Recording interval } \\
\text { (min) }\end{array}$ & $\begin{array}{l}\text { Start of } \\
\text { recording }\end{array}$ & $\begin{array}{l}\text { End of } \\
\text { recording }\end{array}$ & $\begin{array}{l}\text { Water depth } \\
\text { (m) }\end{array}$ & $\begin{array}{l}\text { Upper layer } 300 \mathrm{kHz} \\
\text { ADCP }\end{array}$ & $\begin{array}{l}\text { Sub-surface Layer } \\
75 \mathrm{kHz} \text { ADCP }\end{array}$ & $\begin{array}{l}\text { Deep layer Single-point } \\
\text { DCS }\end{array}$ \\
\hline Mooring 1 & 10 & Jan. 16, 2009 & Jul. 26, 2009 & 1820 & $\begin{array}{l}2 \mathrm{~m} \text { depth cells from } 10 \\
\text { to } 78 \mathrm{mbsl}\end{array}$ & $\begin{array}{l}16 \mathrm{~m} \text { depth cells from } \\
78 \text { to } 446 \mathrm{mbsl}\end{array}$ & $\begin{array}{l}\text { Every } 250 \mathrm{~m} \text { from } 720 \text { to } \\
1720\end{array}$ \\
\hline Mooring 2 & 20 & Sept. 22, 1997 & Oct. 27, 1998 & 1385 & $\begin{array}{l}4 \mathrm{~m} \text { depth cells from } 4 \\
\text { to } 50 \mathrm{mbsl}\end{array}$ & $\begin{array}{l}8 \mathrm{~m} \text { depth cells from } 50 \\
\text { to } 193 \mathrm{mbsl}\end{array}$ & $\begin{array}{l}\text { Every } 200 \mathrm{~m} \text { from } \\
380-1380\end{array}$ \\
\hline
\end{tabular}




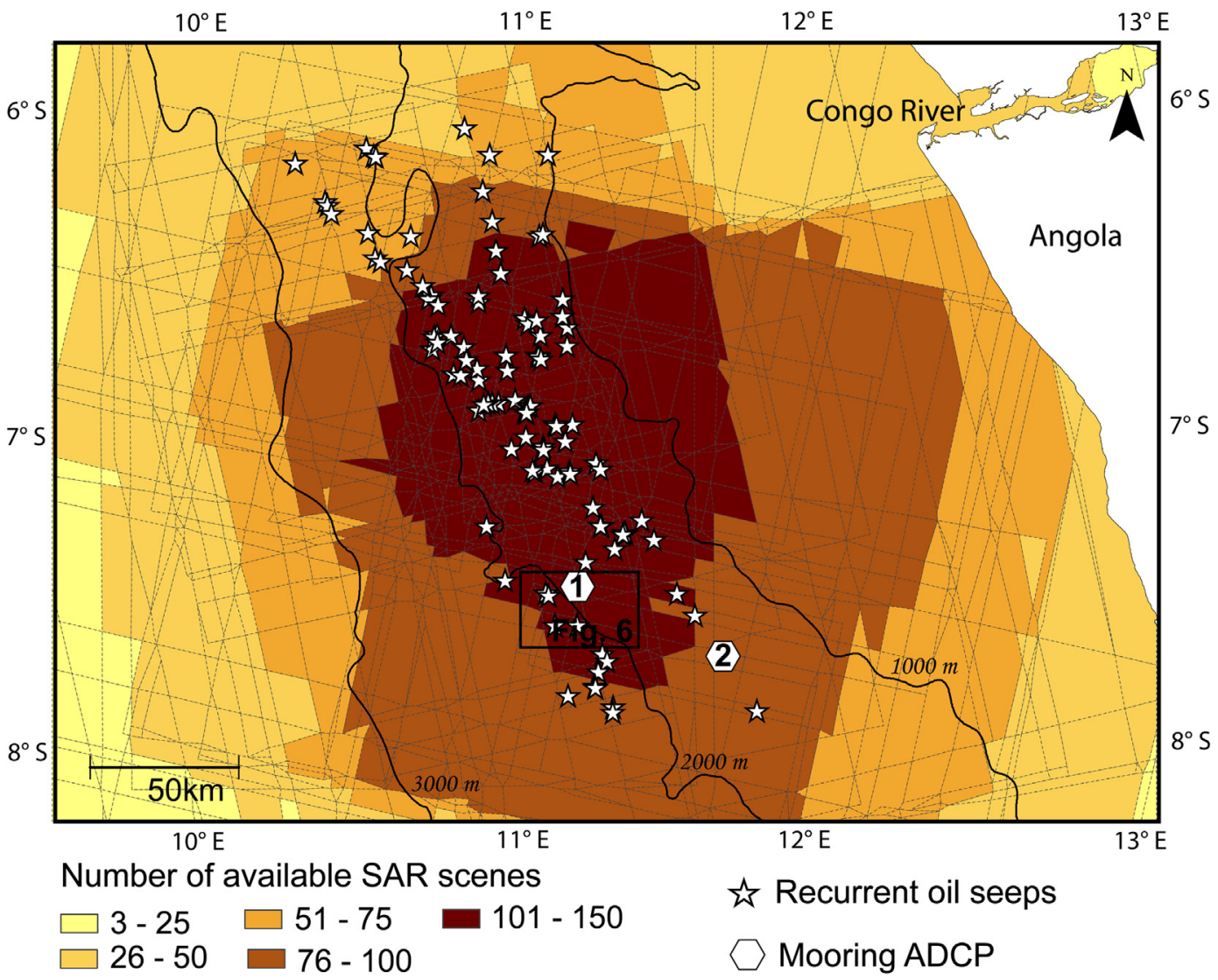

Fig. 2. Compilation stack of SAR data with location of recurrent seep sites.

potential droplet deflection.

The recording characteristics of both moorings helped estimate the probable deflection of oil droplets expelled at natural seep sites using two different methods. Mooring 1 data were used to link spot observations of sea surface oil slicks and the probable seafloor origin. Mooring 2 data were used to compare the distribution of the modeled horizontal deflection over a longer period and was confronted to the deflection values measured during the bi-decadal monitoring of natural oil seepage with satellite images.

We completed our dataset with a CTD (conductivity, temperature, depth) profile acquired in the study area in January 2009 providing water properties with vertical measurements intervals of $50 \mathrm{~cm}$ across an $1820 \mathrm{~m}$ water column.

\subsubsection{Remote sensing inventory of natural oil seep sites}

The Synthetic Aperture Radar (SAR) system sends electromagnetic waves to the earth's surface and retrieves the backscattered signal (e.g., McCandless and Jackson, 2003). Based on Bragg's scattering, the technique provides an efficient means for measuring wind-induced seasurface roughness. The presence of oil slicks strongly affects the seasurface roughness and significantly reduces the amount of backscattered energy to the satellite, accounting for the Fresnel specular reflection. Sea surface covered by oil seepage appears as low radiometric areas on SAR images (e.g., Espedal and Wahl, 1999; Johannessen et al., 2000; Espedal and Johannessen, 2000; Williams and Lawrence, 2002; Zatyagalova et al., 2007; Ivanov et al., 2007; Garcia-Pineda et al., 2010; Körber et al., 2014; Jatiault et al., 2017).

We based our analysis on a stack of overlapping SAR scenes acquired as X-band (wavelength from 2.5 to $3.75 \mathrm{~cm}$ ) and C-band (wavelength from 3.75 to $7.5 \mathrm{~cm}$ ) data, which are the most suitable
Table 3

Inventory of SAR scenes collection characteristics.

\begin{tabular}{lllll}
\hline Satellite/ Sensor & $\begin{array}{l}\text { Period of } \\
\text { imagery }\end{array}$ & Wavelength & $\begin{array}{l}\text { Pixel } \\
\text { Spacing } \\
\text { (m) }\end{array}$ & $\begin{array}{l}\text { Amount of } \\
\text { SAR data }\end{array}$ \\
\hline $\begin{array}{c}\text { ERS/Image Mode } \\
\quad \text { Precision }\end{array}$ & $1994-2001$ & C $(5.8 \mathrm{~cm})$ & 12.5 & 17 \\
$\begin{array}{c}\text { Envisat /Wide } \\
\quad \text { Swath Mode }\end{array}$ & $2002-2012$ & $\mathrm{C}(5.8 \mathrm{~cm})$ & 75 & 46 \\
$\begin{array}{l}\text { RADARSAT -2 } \\
\text { Cosmo-SkyMed } \\
\text { TerraSAR - X }\end{array}$ & $2005-2012$ & $\mathrm{C}(5.3 \mathrm{~cm})$ & $25-50$ & 7 \\
\hline
\end{tabular}

wavelengths for detecting surface oil slicks, especially for the recognition of thinnest oil films (Gade and Alpers, 1998; Leifer et al., 2012). The entire SAR collection consisted of long-term monitoring of 156 scenes collected at variable intervals over 21 years, tasked for the monitoring of petroleum activities in the area and coupled with freeaccess data (Table 3 ).

The SAR density coverage varied across the study area, but the oilseeping province was imaged with a large stack of images consisting of 50 and 150 overlapping scenes (Fig. 2). The time interval of current mooring 1 measurements (Jan. 16, 2009 - Jul. 26, 2009) corresponds to a period without $\mathrm{X}$ and C-bands SAR data coverage.

To get simultaneous acquisitions of SAR data and current measurements, we supplemented the dataset with L-band SAR scenes, also suitable for oil slick recognition even though the volume of detected oil might be underestimated (Gade and Alpers, 1998). The SAR coverage during ACDP records consisted only of 10 ALOS (Advanced Land Observation Satellite) scenes, among which one scene, dated June 30, 


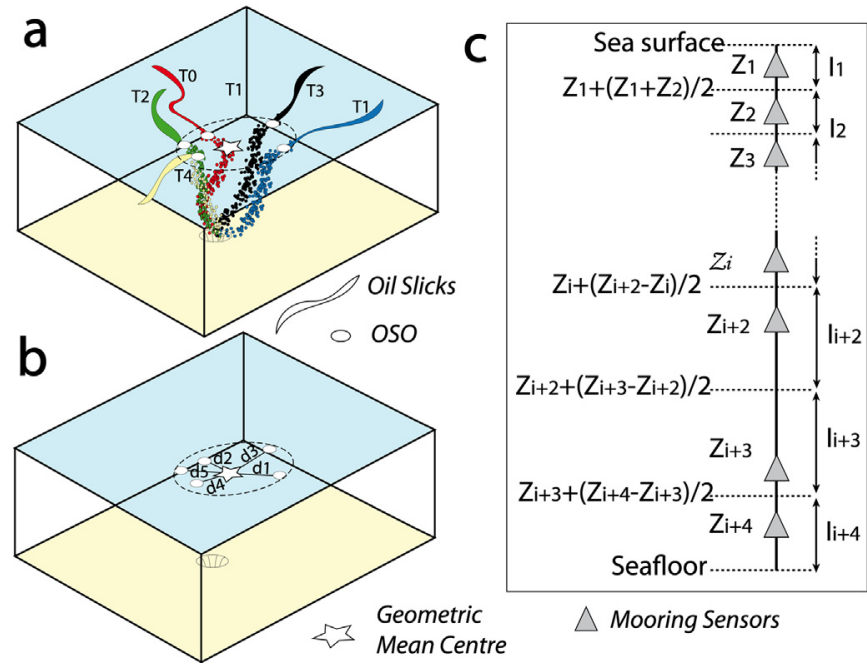

Fig. 3. a. Schematic representation of the methodology used to quantify the deflection of oil droplets in the water column. Oil Slick Origins (OSO) were drawn from the detectable proximal edge of seepage slicks on the compilation stack of SAR data. b. The distribution of the deflection value was assessed from the distance and orientation between the GMC (Geometric Mean Centre) and individual OSO. c. Representation of the vertical distribution of sensors $\left(Z_{i}\right)$ and the methodology used to define water column intervals $\left(I_{i}\right)$ based on the depth of sensors pairs (see details in text).

2009, that notified the presence of oil slicks.

We mapped about 3000 seepage slicks using local radiometry anomalies identified from the analysis of overlapping SAR scenes that were reliably associated with a hundred of recurrent seep sites (Fig. 2; Jatiault et al., 2017). The seeping province was located about $150 \mathrm{~km}$ offshore Angola at water depths ranging from 1200 to $2700 \mathrm{~m}$. The detectable proximal edge of recurrent oil slicks (i.e. the location of the last oil droplet of an individual seep at the sea surface) provides the location of the Oil Slick Origins (OSO; Garcia-Pineda et al., 2010; Fig. 3). The spatial distribution of OSO provided an efficient means for isolating the horizontal deflection of oil droplets produced during the transit period within the water column, compared against the sea surface displacement (winds and surface currents).

Based on the compilation map of individual OSO, we computed the centroid of OSO clusters, namely the GMC (Geometric Mean Centre; Fig. 3a, b). The GMC location provided the average location where oil impacts the sea surface and was reported as the most probable location of the origin of the oil expelled from the seafloor (Garcia-Pineda et al., 2010; Körber et al., 2014).

\subsection{Methods}

3.2.1. Backward oil plume trajectory combining simultaneous SAR and ACDP records

When SAR scenes and current measurements were concomitant, the modeling of the horizontal deflection of oil droplets through the water column was assessed by computing the backward trajectory of oil droplets using ADCP measurements during the transit period before SAR acquisition. We used mooring 1 data, which was located $15 \mathrm{~km}$ from recurrent oil seep sites (Fig. 2). We considered the ascension velocities of oil droplets reported in the literature (i.e., between 2 and $50 \mathrm{~cm} \mathrm{~s}^{-1}$, see Table 1). Given the water depth at mooring $1(1820 \mathrm{~m})$, the range of ascension velocity implied a time window of $1-25 \mathrm{~h}$ prior to the SAR scene. The backward rise path of oil droplets from the location of the OSO on SAR scene was computed from the iterative addition of the travelled horizontal distance through subsequent intervals across the water column. The depth intervals were defined between the median positions of two successive pairs of current measurements (Fig. 3c). The travelled horizontal distance for each depth interval took into account the transit time of the droplet in this interval, considering the intensity and direction of the current concomitantly measured at this level. Hence, we estimated the location of the potential seepage site on the seafloor for the different ascension velocities. The resulting modeled sites were superimposed to the detailed seafloor features using a high-resolution bathymetric map (12.5 m lateral resolution).

\subsubsection{Horizontal deflection distribution over time}

To complement the deflection assessed from simultaneous implementation of SAR and ADCP data, we performed a statistical analysis of the observed deflection during the long-term acquisition of SAR scenes. Sub-surface water column measurements were unavailable during the SAR scene monitoring (1994-2014), and the only available current measurements were restricted to surface measurements, which are inappropriate for quantifying the water column deflection. The inventory of the location of recurrent seep sites (a hundred of sites concentrated around OSO clusters; Fig. 2) was used to quantify the underwater deflection.

The method consisted in measuring the distance and orientation of the spatial spreading of OSO from individual GMC. It provided a complementary technique for estimating the horizontal deflection in the water column when current measurements were unavailable (Fig. 4). We gathered the horizontal deflection assessed from each individual recurrent seep site to obtain a unique OSO population.

Finally, the theoretical OSOs were estimated at each mooring site considering a range of ascension velocities and the temporal variability of currents in the water column. An ensemble of possible forward

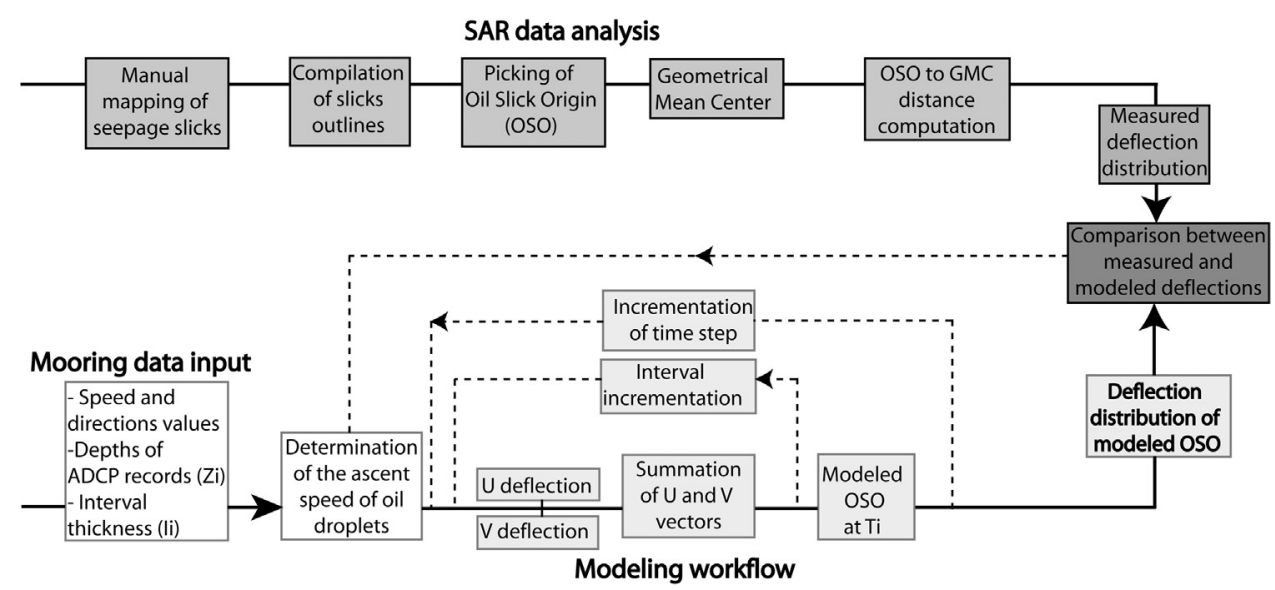

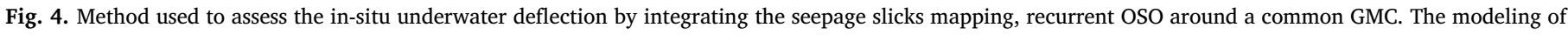
the deflection used current measurements at moorings 1 and 2 for different oil droplet ascension velocities. 

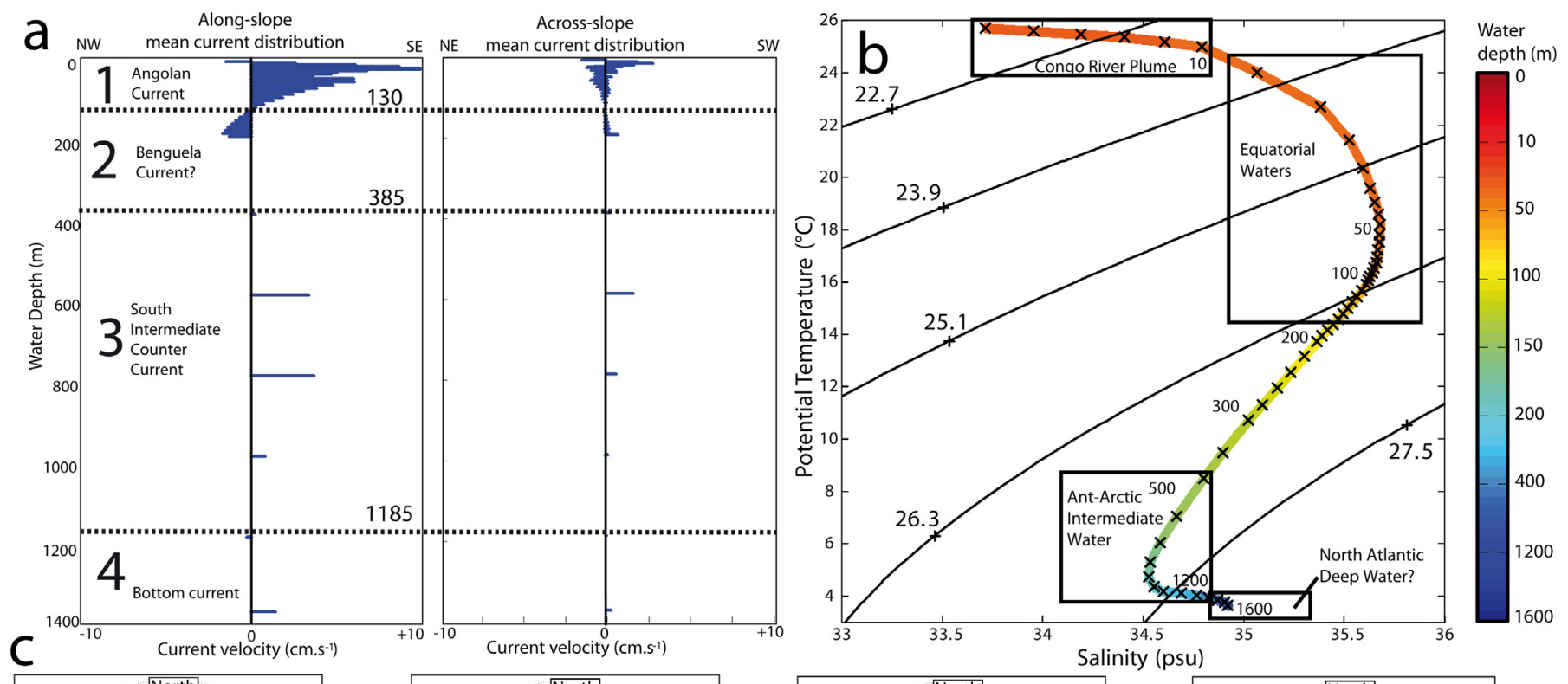

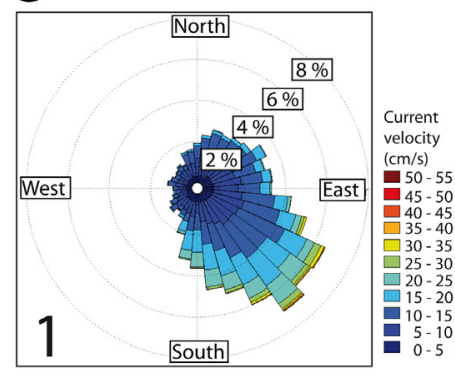

Subsurface currents: $8-130 \mathrm{~m}$

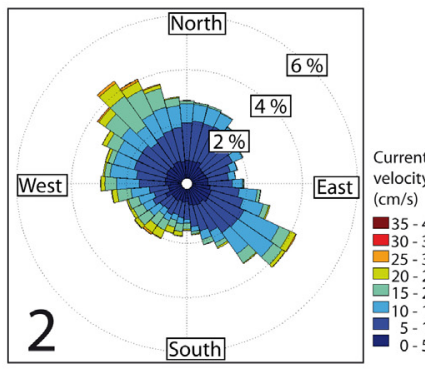

Intermediate currents: 130 - 385 m

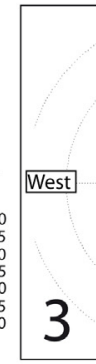

3

South

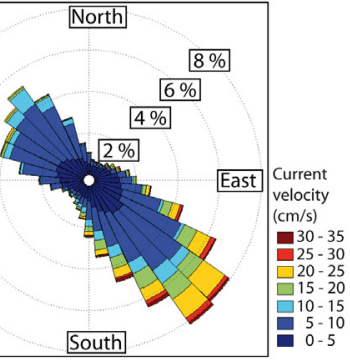

$385-1185 \mathrm{~m}$

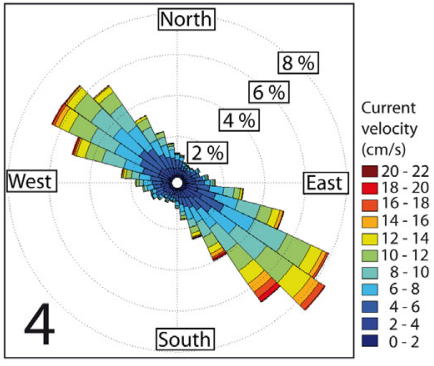

Bottom currents: $1185-1385 \mathrm{~m}$

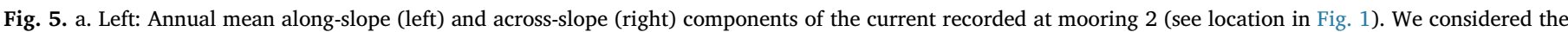

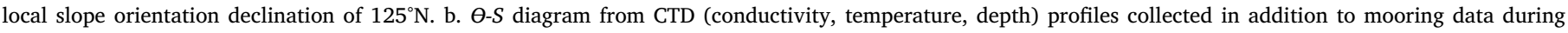

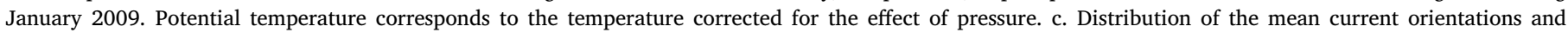

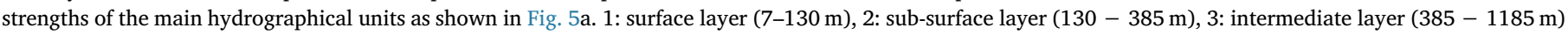
4: bottom layer $(1185-1385 \mathrm{~m})$.

droplet deflections was computed for every current-measurement timestep (every $10 \mathrm{~min}$ during 6 months for mooring 1, and every $20 \mathrm{~min}$ during 13 months for mooring 2). In those models, all seafloor origins were centred on the mooring locations, and we calculated the theoretical lateral deflection of oil droplets towards the sea surface, taking into consideration a transit period depending on the ascension velocity. The spatial spreading of the modeled OSO ensemble was compared against the observed deflection distribution (Fig. 4). The understanding of the basin hydrodynamics independently from seasonal variations is meaningful in this study because SAR scenes were acquired independently throughout the year. Although mooring point 2 was located further from the main seeping province (Fig. 2), it benefited from a full year of records compared to mooring 1 .

\section{Results}

\subsection{Current distribution during the monitoring period}

The analysis of current and CTD measurements acquired in complement to mooring data shows that water masses and associated currents were layered across the water column in the study area (Fig. 5a). The fresh and warm waters layer of the first $10 \mathrm{~m}$ probably corresponds to the Congo plume (Fig. 5b). The sub-surface layer (between 10 and $130 \mathrm{~m}$ in Fig. $5 \mathrm{c})$ is warmer $\left(16-24^{\circ} \mathrm{C}\right)$, saltier (35.5 psu) and gather similar characteristics to those of the Angolan Current described by Hardman-Mountford et al. (2003). The sub-surface layer waters flowed mostly along-slope, towards the southwest, at velocities of $0-35 \mathrm{~cm} \mathrm{~s}^{-1}$. From $130 \mathrm{~m}$ to roughly $385 \mathrm{~m}$, the flow was predominantly along-slope, oriented to the northwest (Fig. 5c). The Benguela Counter Current intrusion along the Angolan coast probably corresponds to this intermediate flow, even though the reported influence is restricted to shallow waters (Schneider et al., 1996; Hopkins et al., 2013). The deep $(385-1185 \mathrm{~m})$ and bottom $(1185-1600 \mathrm{~m})$ currents were also oriented along-slope, with the mean flow towards the southeast (interval 3 and 4 in Fig. 5c) with peak velocities around $20 \mathrm{~cm} \mathrm{~s}^{-1}$. These layers probably correspond to the Antarctic Intermediate Water (AAIW) and North Atlantic Deep Water (NADW), transported by the Southern Intermediate Counter Current (SICC).

The temperature and the salinity values (Fig. 5b) demonstrated that the seawater density gradient was greater than $5 \mathrm{mgl}^{-1}$ between the bottom waters $\left(<27.5 \mathrm{gl}^{-1}\right)$ and the near-surface waters $\left(>22.7 \mathrm{gl}^{-1}\right)$. The water density strongly decreased from $100 \mathrm{~m}$ upwards due to a salinity contrast between the Angolan Current and the Congo River plume.

\subsection{Evidence of active hydrocarbon seepage}

From Jan. 16, 2009 to Jul. 26, 2009 when the currents were being 

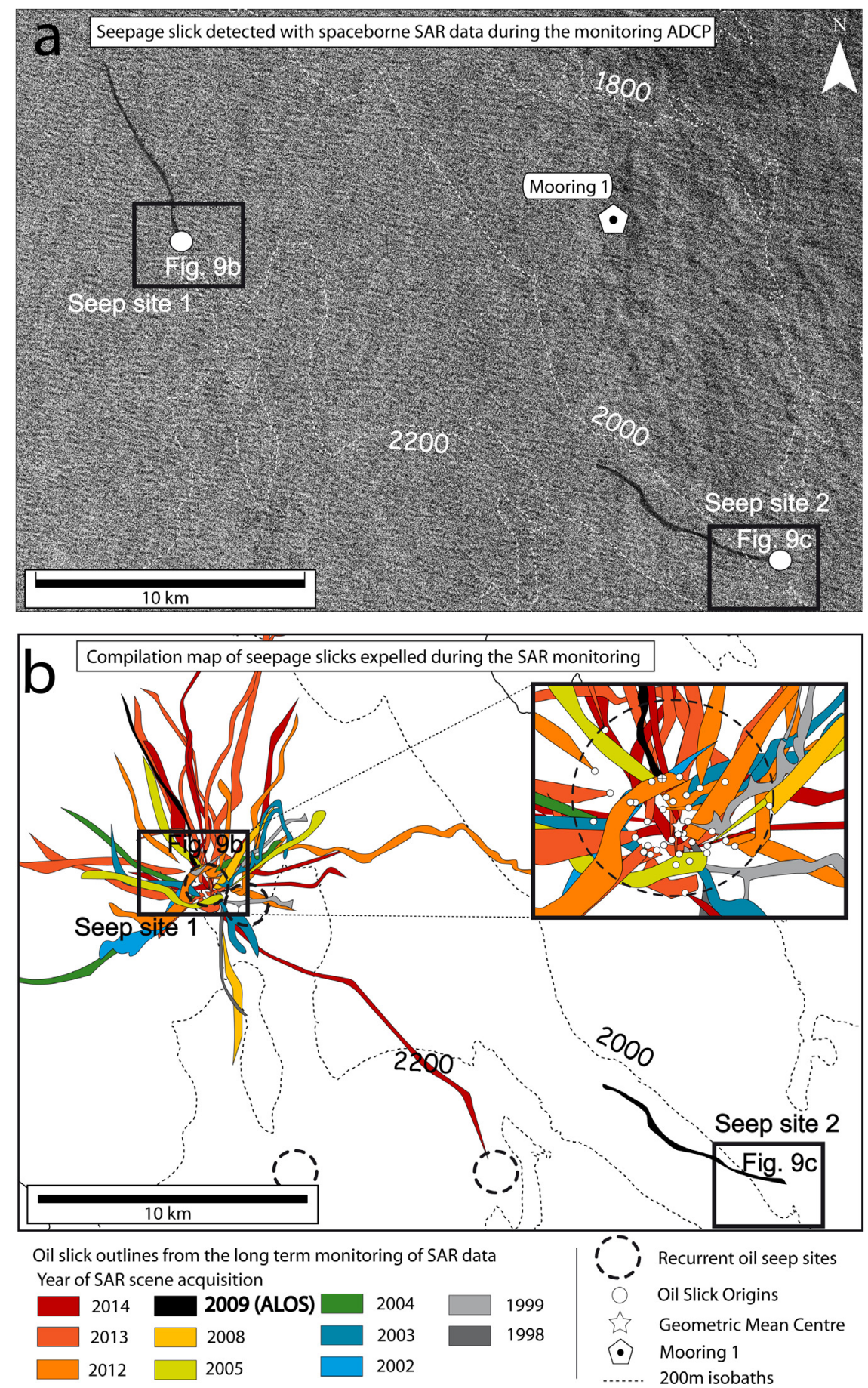

Fig. 6. a. Extract of the ALOS SAR scene acquired on June 30, 2009 zoomed-in on the location of mooring 1 and closest oil slicks (scene provided by the Japan Aerospace Exploration Agency). Two oil slicks are outlined in black polylines for the display. OSOs are spotted from the proximal edge of recurrent oil slicks deduced from the slicks compilation map. b. Compilation map of seepage slicks identified from the analysis of the 103 overlapping SAR scenes. The color-scale refers to the year of observation. The black box in the right top corner displays the slicks compilation map focused on the probable surfacing area.

recorded (mooring 1), a SAR scene was gathered on June 30, 2009. It showed the presence of seven areas characterized by local decreases in the radiometric values and moderate reflectivity contrasts between oily covered areas and oil-free water. Two slicks characterized by continuous elongated black patches ranging from 5 to $20 \mathrm{~km}$ in length were observed near mooring site $1(\sim 15 \mathrm{~km})$ with orientation respectively varying from $290^{\circ} \mathrm{N}$ and $330^{\circ} \mathrm{N}$ for slicks site 1 and 2 , respectively.
Slicks orientations are aligned with near-surface currents flowing towards westward $\left(268^{\circ} \mathrm{N}\right)$ at a speed of $20 \mathrm{~cm} \mathrm{~s}^{-1}$ during the SAR acquisition. Slick observed at site 1 is comparable to the 41 individual slicks interpreted from 102 overlapping SAR scenes during the longterm SAR monitoring (1994-2014). As shown on the map, slicks have different orientation through time; however, all slicks observed at site 1 point out to the same origin and likely associated with recurrent seep on 
Table 4

Inventory of modeled deflection values expressed in distance and orientation for a range of probable ascension velocities, considering a water depth of $1820 \mathrm{~m}$ (depth of mooring 1). The orientation is provided for a backward deflection from the slicks observed from the sea surface towards the seafloor emission point. It also presents the deflection orientation for forward modeling from the seafloor origin towards the sea-surface slick.

\begin{tabular}{lllll}
\hline $\begin{array}{l}\text { Ascension } \\
\text { velocity } \\
\left(\mathbf{c m} . \mathbf{s}^{-\mathbf{1}}\right)\end{array}$ & $\begin{array}{l}\text { Transit } \\
\text { period } \\
\text { (hh: } \mathbf{~ m m})\end{array}$ & $\begin{array}{l}\text { Modeled } \\
\text { distance of } \\
\text { deflection }(\mathbf{m})\end{array}$ & $\begin{array}{l}\text { Backward } \\
\text { deflection } \\
\left.\text { angle } \mathbf{(}^{\circ}\right)\end{array}$ & $\begin{array}{l}\text { Forward } \\
\text { deflection } \\
\text { angle } \mathbf{(}^{\circ} \text { ) }\end{array}$ \\
\hline 2 & $25: 15$ & 1255 & 224 & 44 \\
2,5 & $20: 15$ & 1247 & 218 & 38 \\
3 & $16: 50$ & 654 & 171 & 351 \\
3,5 & $14: 25$ & 593 & 169 & 349 \\
4 & $12: 35$ & 488 & 168 & 348 \\
4,5 & $11: 15$ & 394 & 175 & 355 \\
5 & $10: 05$ & 409 & 174 & 354 \\
6 & $8: 25$ & 399 & 177 & 357 \\
7 & $7: 15$ & 373 & 168 & 348 \\
8 & $6: 20$ & 379 & 196 & 16 \\
9 & $5: 35$ & 182 & 176 & 356 \\
10 & $5: 00$ & 250 & 157 & 337 \\
15 & $3: 20$ & 169 & 209 & 29 \\
30 & $1: 41$ & 145 & 210 & 30 \\
50 & $1: 00$ & 127 & 211 & 31 \\
\hline
\end{tabular}

the seafloor (Fig. 6b).

Based on the high repeatability of slicks observations, site 1 can be interpreted as a high activity seep with a slick reoccurrence rate of $40 \%$, as opposed to site 2 with only one observable slick (Fig. 6a, b).

\subsection{Computation of the horizontal deflection of oil droplets}

The deflection of oil droplets during their transit time through the water column depends on their ascension velocity (Table 4).

The calculated transit period ranged from $1 \mathrm{~h}$ to $25 \mathrm{~h}$ depending on the ascension velocity (Table 4). During the $24 \mathrm{~h}$ preceding the SAR scene acquisition, currents were constant over time (Fig. 7). Vertical shear layers appeared between depths of 1200 and $700 \mathrm{~m}$, due to current reversal (Fig. 7). Assuming that the current configuration was probably similar between the way-in (entering) moment and the wayout (leaving) moment in incremental intervals, this suggests that the approximation of a constant deflection during the transit time within intervals ( $>3 \mathrm{~h} \mathrm{30}$ ) is fairly satisfactory.

The backward deflections and the locations of the potential seepage sites on the seafloor with the different ascension velocities for the June 30, 2009 ALOS SAR scene are shown in Fig. 8. The seafloor origin is located southwards of the OSO location when ascension velocities are greater than $3 \mathrm{~cm} \mathrm{~s}^{-1}$; the location is southwesterly for lower ascension velocities $\left(<3 \mathrm{~cm} \mathrm{~s}^{-1}\right)$. The deflection distance increased with decreasing ascension velocity (Table 4), between $150 \mathrm{~m}$ for the highest values $\left(50 \mathrm{~cm} \mathrm{~s}^{-1}\right)$ and $1255 \mathrm{~m}$ for the lowest one $\left(2 \mathrm{~cm} \mathrm{~s}^{-1}\right.$; Fig. 8a; Table 4).

\subsection{Connecting sea-surface slicks with seep-related seafloor features}

Reverse deflections modeling shows potential seafloor origin located southward of the surface slick location (Fig. 8). In this direction, the proximal edge of both slicks (seep sites 1 and 2. Fig. 6) is in the

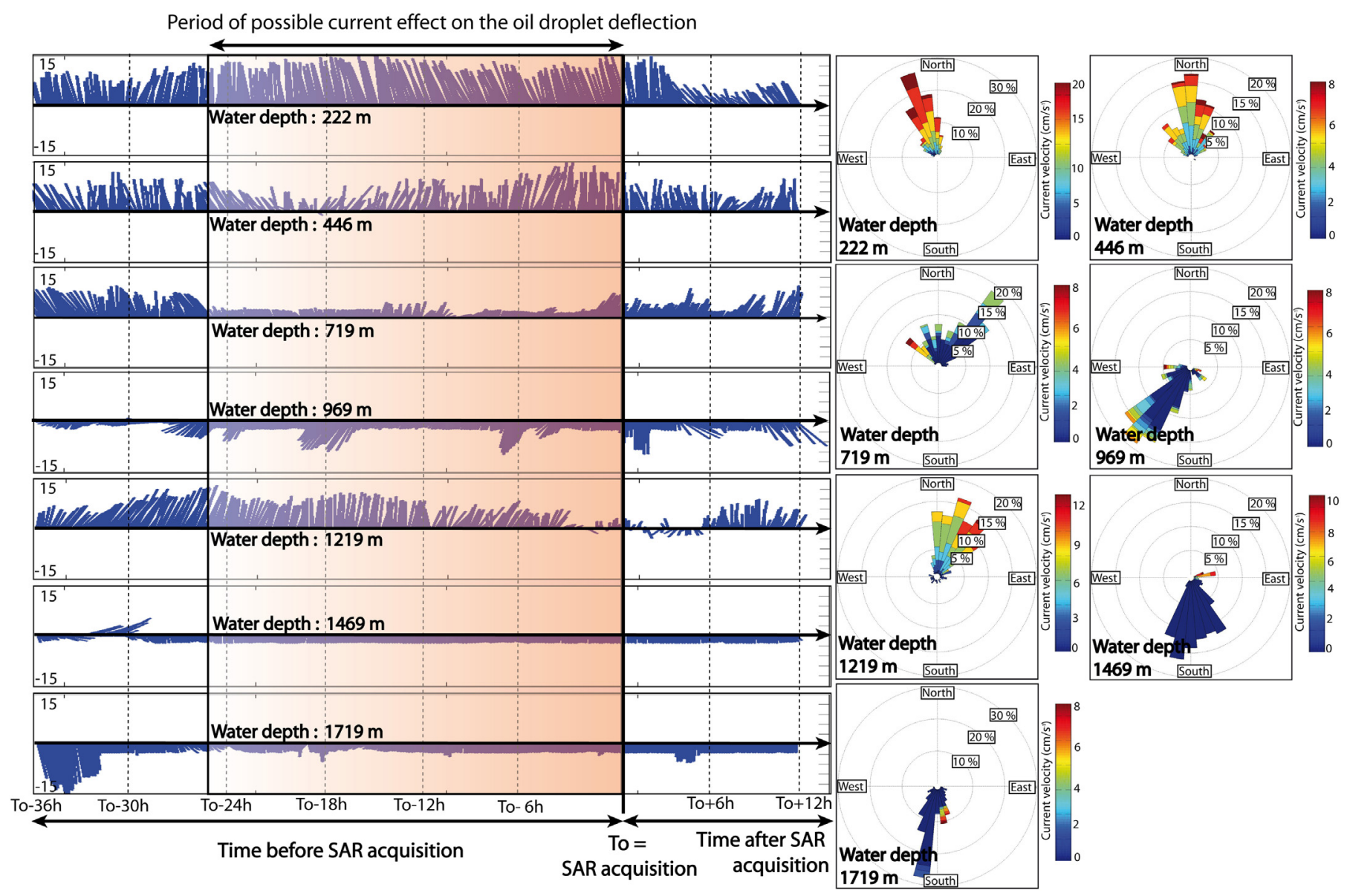

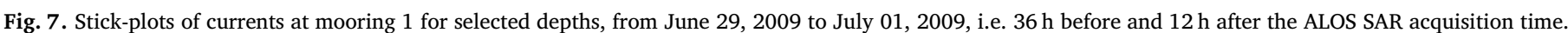

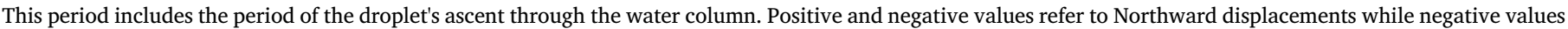
refer to Southward displacement. The current velocity is given in $\mathrm{cm} \mathrm{s}^{-1}$. 

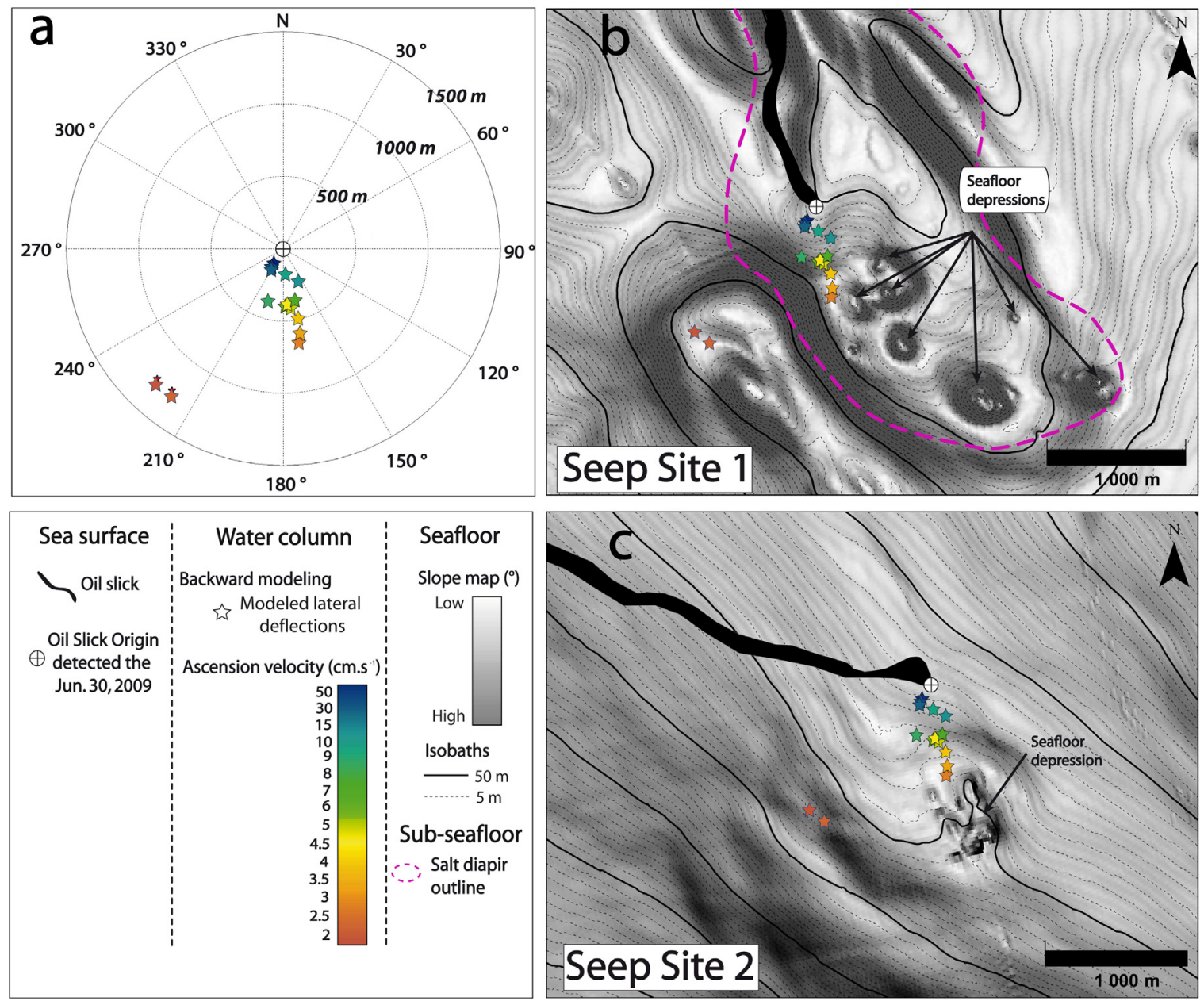

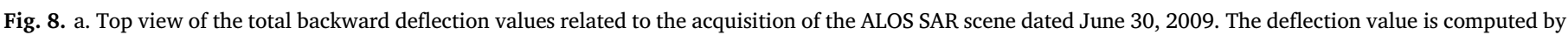

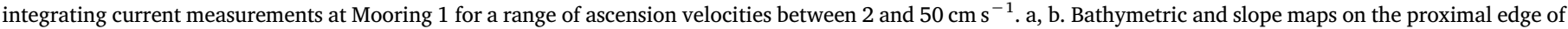

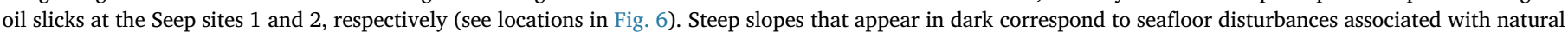

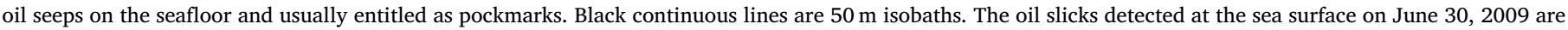
superimposed with the OSO and the modeled deflections for a range of probable ascension velocities (colored stars).

vicinity of the vertical projection of seafloor depressions (Fig. 8b, c) interpreted as pockmark formed by hydrocarbon expulsion on the seafloor.

The water depth at seep site 1 is roughly $2100 \mathrm{~m}$. The broad ovoidshaped bathymetric relief represents the seafloor expression of an underlying salt diapir (outlined in pink dashed lines). The active seeprelated seafloor features are characterized by seven individual sub-circular depressions on the present day seafloor, also known as pockmarks. The edge of the proximal pockmark was close to the location of the modeled seafloor origin using ascension velocities ranging from 3 to $7 \mathrm{~cm} \mathrm{~s}^{-1}$ (Fig. 8b).

At seep site 2, where the water depth is $1940 \mathrm{~m}$, the seafloor disturbance is characterized by a large depression $(800 \mathrm{~m}$ in diameter) scattered with micro-depressions (Fig. 6c). The main depression was close to the location of the modeled seafloor origin using ascension velocities ranging from 3 to $4 \mathrm{~cm} \mathrm{~s}^{-1}$ (Fig. $8 \mathrm{c}$ ).

The best spatial overlap between modeled seafloor origin and seeprelated seafloor features corresponds to model using ascension velocity of $3 \mathrm{~cm} \mathrm{~s}^{-1}$ for both seep sites 1 and 2. Fig. 9a illustrates the modeled path of rising oil droplets through the water column from the seafloor origin (red star) and the OSO surface using an ascension velocity of $3 \mathrm{~cm} \mathrm{~s}^{-1}$. The modeled deflection shows strong variations in the direction of droplet deflection through the water column, with a total travelled distance of $1200 \mathrm{~m}$ (Fig. 9b). The orientation of the nearsurface deflection was in agreement with the surface slick direction.

\subsection{Statistical assessment of the horizontal deflection}

In addition to the assessment of the deflection from the simultaneous acquisition of SAR scenes and mooring data, we inspected the distribution of roughly 3000 deflection distances between OSO and their GMC from SAR acquired over 21 years (Fig. 11). The OSO were deflected radially with a distance of $0-2500 \mathrm{~m}$ from the GMC. Most deflection distances occurred between 500 and $1000 \mathrm{~m}$, with a peak around $750 \mathrm{~m}$.

The theoretical dispersion of OSO was assessed from the repetitive calculation of the deflection distance using the current measurements of the two mooring sites and with different ascension velocities. The number of deflection scenarii was defined from the mooring sampling interval (10 min for mooring 1 and $20 \mathrm{~min}$ for mooring 2) and the period of records (6 months for mooring 1 and 1 year for mooring 2). Assembling theoretical OSO provided an additional approach for quantifying the probable deflection depending on the ascension velocities (see appendices; Figs. A.1 and A.2). The ascent modeling was 

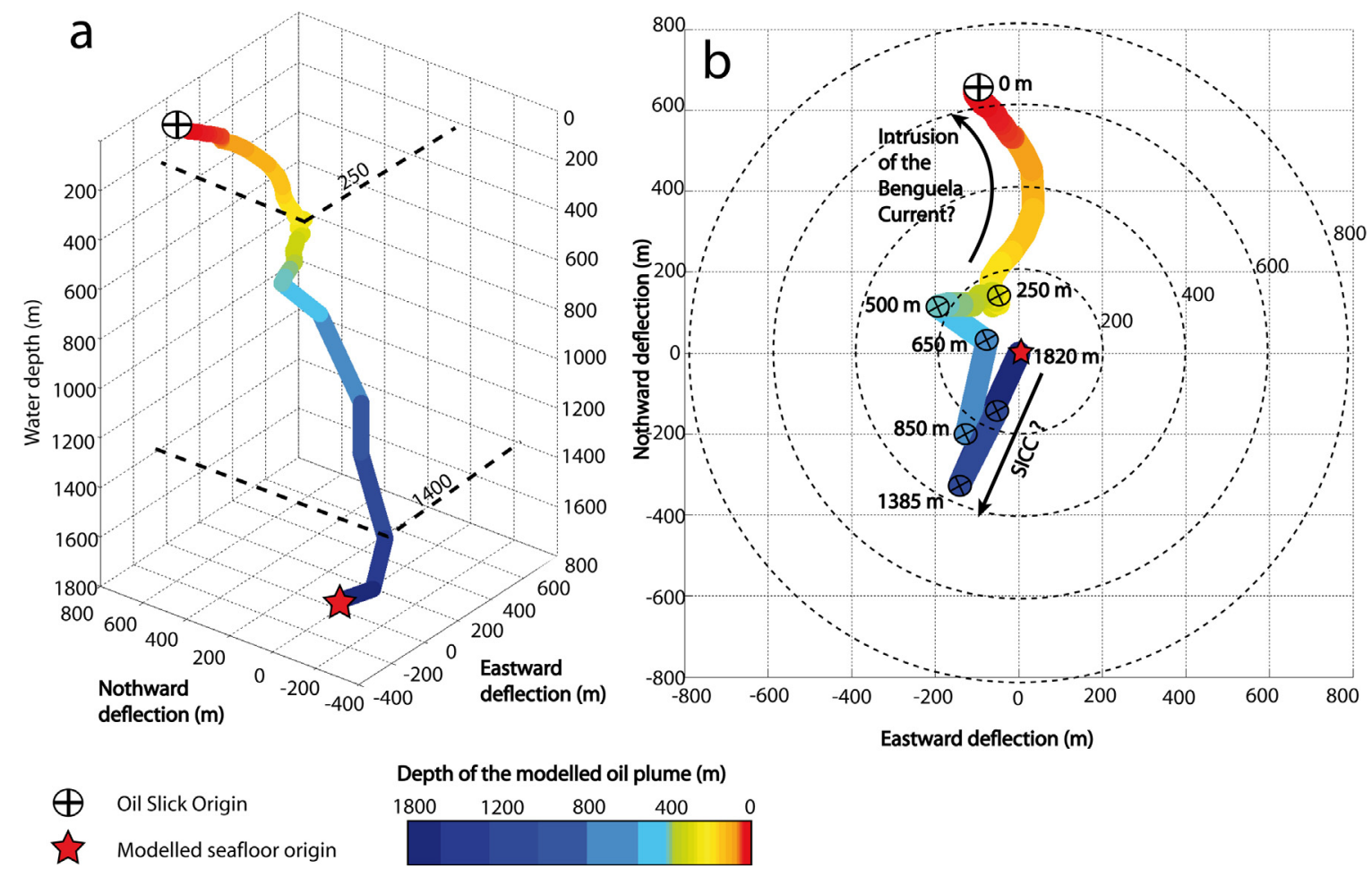

Depth of the modelled oil plume $(\mathrm{m})$

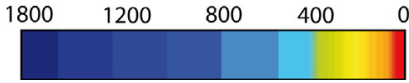

Fig. 9. a. Modeled rise path of the oil droplets (June 30, 2009) in the water column using Mooring 1 records for an ascent velocity of $3 \mathrm{~cm} \mathrm{~s}{ }^{-1}$. The location of the modeled seafloor origin is shown by the red star and the OSO by a cross in a white circle. b. Top view of oil plume location across the water column.

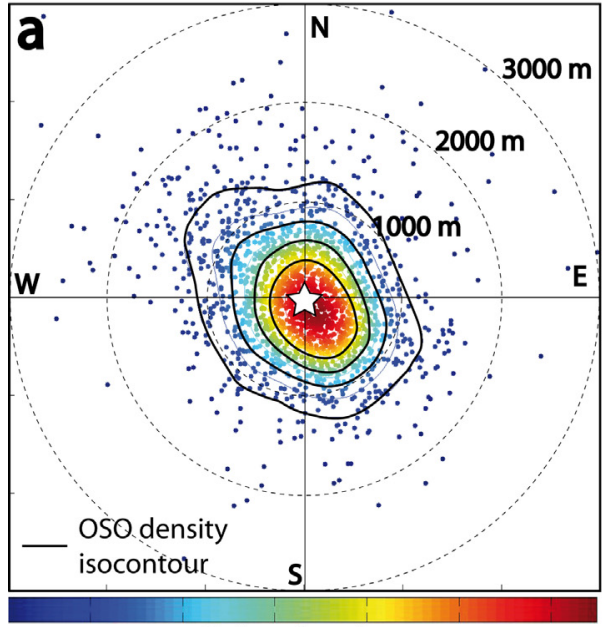

Point density

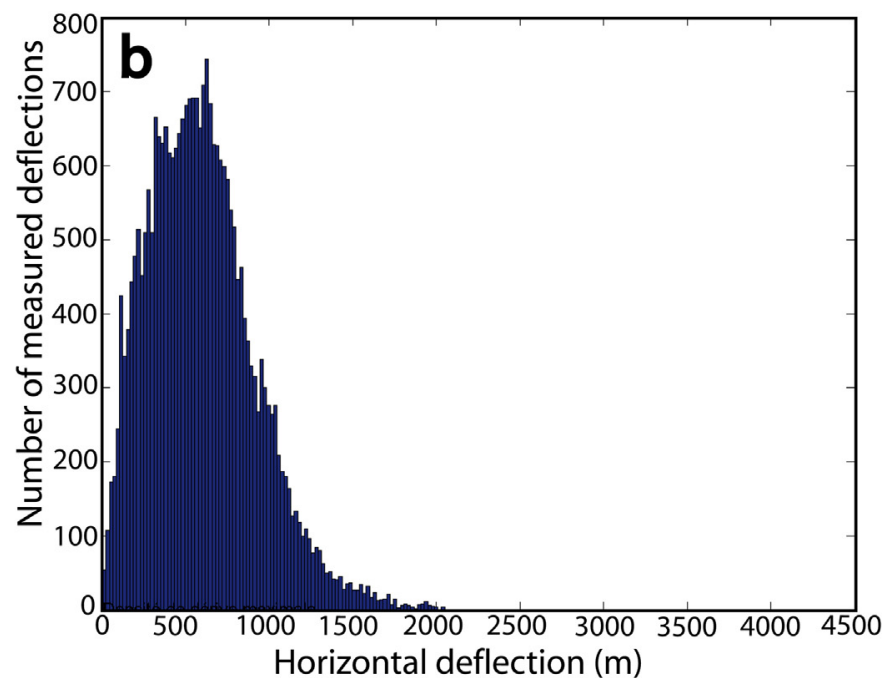

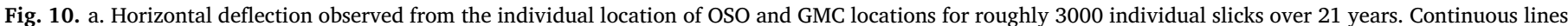
are isodensity markers. b. Histogram of the distribution of the distances between OSO and their GMC.

reproduced for each time step in the recording periods, resulting in the computation of 27300 theoretical OSO for mooring 1 and 28800 OSO for mooring 2. The distribution of OSO deflection distances is displayed in Fig. 12a for Mooring 1 and Fig. 12b for Mooring 2, for the range of ascension velocities reported in the literature by comparison with the measured deflection distribution.

The deflection associated with velocities ranging from 50 to $10 \mathrm{~cm} \mathrm{~s}^{-1}$ produced restricted deflections (mostly lower than $100 \mathrm{~m}$ ) and the spatial distribution clearly differed from the measured deflections for both mooring 1 or 2 (for more details see appendices; Figs. A.1 and A.2). The measured and computed deflection distributions were quite similar for ascension velocities ranging $6-9 \mathrm{~cm} \mathrm{~s}^{-1}$ (see additional data) and were almost alike for ascension velocities of $8 \mathrm{~cm} \mathrm{~s}^{-1}$ (Fig. 12). Slower ascension velocity values $\left(2-5 \mathrm{~cm} \mathrm{~s}^{-1}\right)$ produce deflections that largely exceeded measured values. The scatter plot of the theoretical OSO locations was characterized by a strong preferential orientation of the droplet deflections along the $140^{\circ} \mathrm{N}-320^{\circ} \mathrm{N}$ direction for Mooring 1 , and $120^{\circ} \mathrm{N}-300^{\circ} \mathrm{N}$ for Mooring 2 (i.e. along the continental slope; Fig. 11c, d). The average modeled deflection (modeled GMC in Fig. 11c, d) located around $350 \mathrm{~m}$ to the northwest for Mooring 

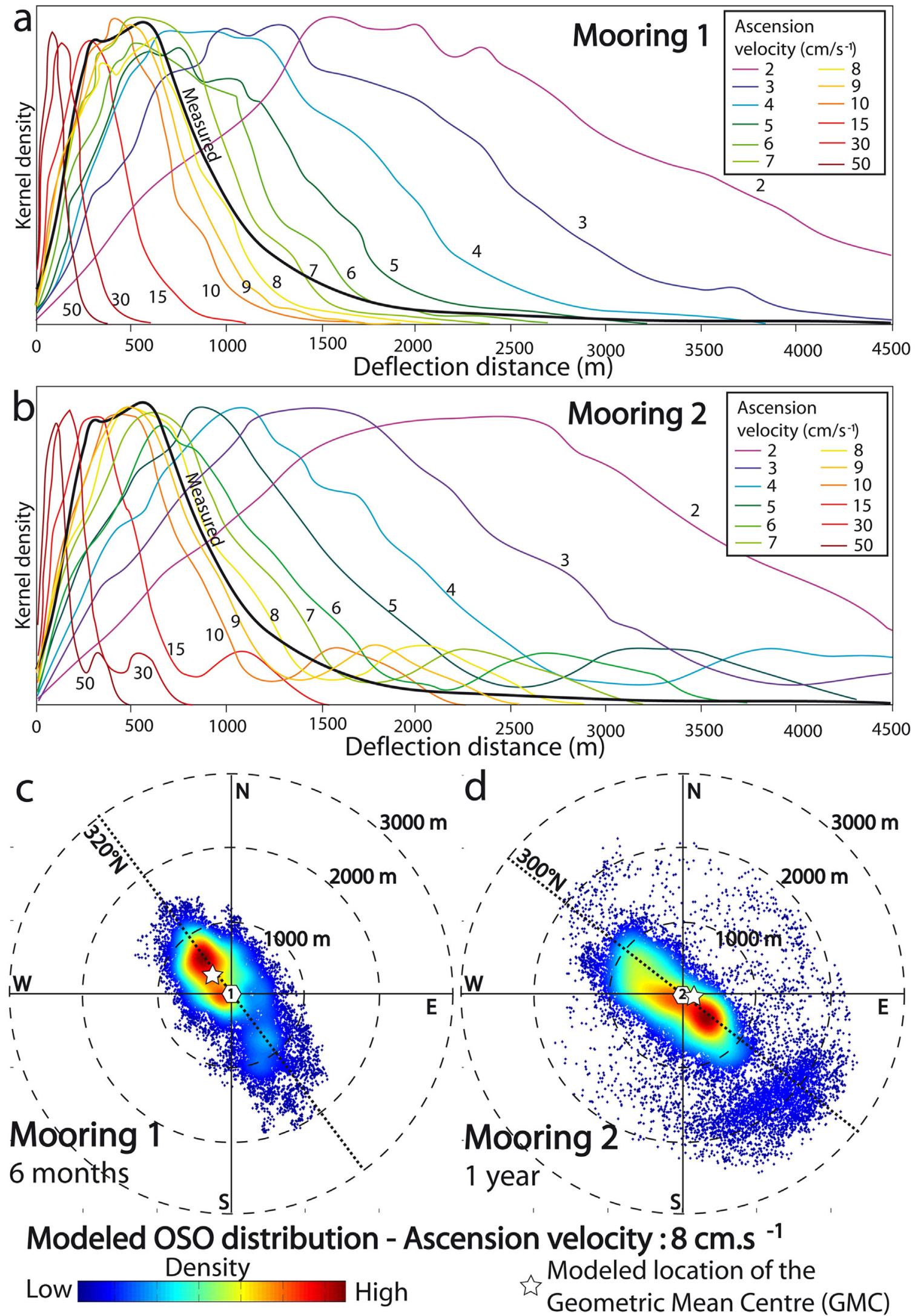

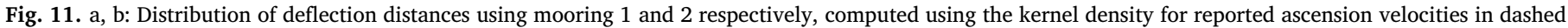

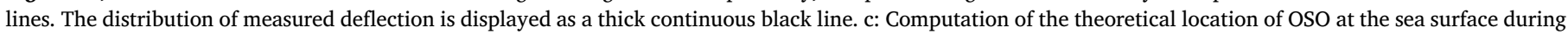

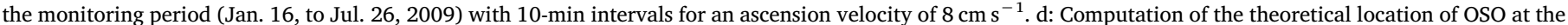
sea surface during the monitoring period (Sep 22, 1997 to Oct 27, 1998) with 20-min intervals for an ascension velocity of $8 \mathrm{~cm} \mathrm{~s}{ }^{-1}$. 


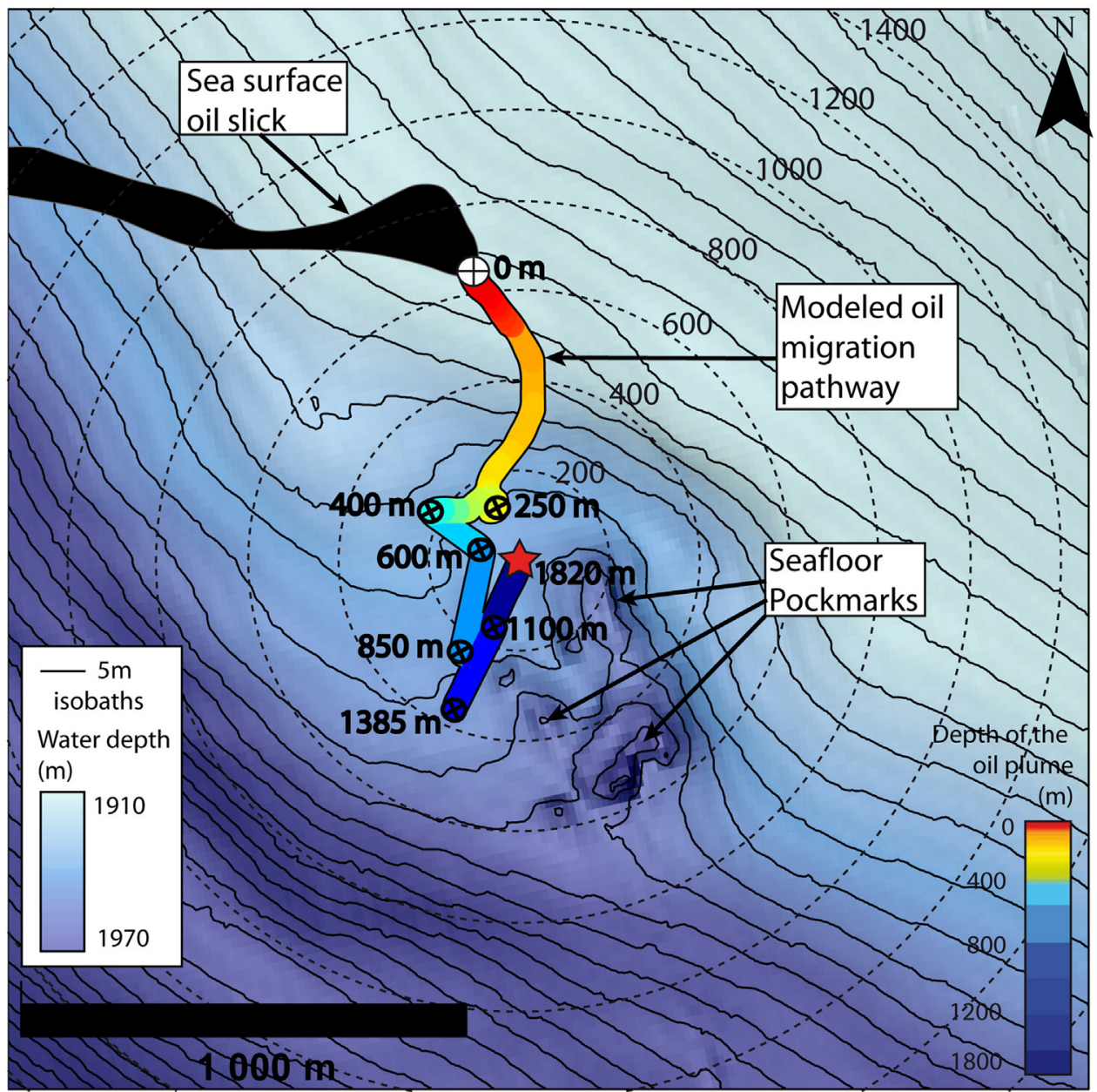

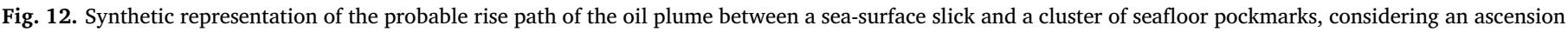

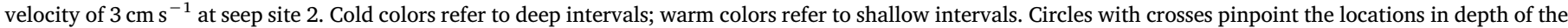
main inflection of rise path of the oil plume.

1 and was almost at the same vertical location $(<150 \mathrm{~m})$ with the theoretical seafloor origin (mooring locations) of expelled oils for Mooring 2.

\section{Discussion}

The aim of this paper is to: (1) quantify the spatio-temporal variation of oil droplets rising through the water column in the Lower Congo Basin, (2) link sea-surface oil slicks with seep-related seafloor features, (3) propose a range of probable rising velocities, (4) and evaluate the deflection offset compared against the water depth. The following discussion aims to establish:

- The accuracy of the model and potential limiting factors.

- The possible behavior variability of rising oil plume through the water column.

- A comparison with predicted ascent models.

- A comparison with published results to understand if deflection values can be compared between study areas.

\subsection{Accuracy of the model}

The calculation based on in-situ mooring measurements and statistical methods developed in this study shows that the best correlation between surface slicks and seep-related seafloor features (i.e. Pockmarks) account for an ascension velocity ranging from $3 \mathrm{~cm} \mathrm{~s}^{-1}$ to $8 \mathrm{~cm} \mathrm{~s}^{-1}$. Although the two methods provided slightly distinct results, the velocity range proposed in this paper corresponds to the lowest reported values in previous studies (from 2 to $50 \mathrm{~cm} \mathrm{~s}^{-1}$; MacDonald et al., 2002; Crooke et al., 2015). The sub-circular depressions observed in the vicinity of the vertical projection of surface area of recurrent oil slicks are interpreted as pockmarks resulting from active or recent fluid flow at the seafloor (King and McLean, 1970; Gay et al., 2006a; Gay et al., 2006b; Gay et al., 2007; Andresen and Huuse, 2011; Andresen, 2012). The reversed deflection model suggests expulsion points in the vicinity of the mapped pockmarks; however remains under-estimated as model seeps do not directly overlap with the pockmark centre (Fig. 12).

We consider that several parameters might induce differences between measured and modeled deflections, thereby limiting the accuracy of the modeling technique that combines concomitant ADCP and SAR acquisitions:

- Even if the Mooring 1 location is only $15 \mathrm{~km}$ from recurrent seep site locations, the underwater current might be slightly different between the seepage and mooring locations.

- The OSO corresponds to the detectable proximal edge of the slicks 
(Garcia-Pineda et al., 2010), which is subjected to great variability in slick thickness. The proximal edge location depends on the SAR detectability threshold of the slick thickness $(0.1 \mu \mathrm{m}$ - MacDonald et al., 1993; National Research Council, 2003) and therefore may be slightly different from the in-situ location.

- The amount of detected oil is significantly underestimated with Lband acquisition compared to X and C bands (Gade and Alpers, 1998). Therefore, although ALOS scenes have a restricted pixel spatial resolution $(12.5 \mathrm{~m})$, the difference between the surface area and the detectable proximal edge is probably increased using L-band satellite images.

- Even if pockmarks corresponds to the seafloor expression of a focused fluid flow (King and MacLean, 1970), oil can emit from discrete sources outwards of the main fluid conduit (MacDonald et al., 2003; Gay et al., 2007; Johansen et al., 2017). Moreover, seafloor emission outlets are subjected to spatio-temporal evolution within seafloor seeps features (Gay et al., 2006a).

- The water depths are greater at site $1(2100 \mathrm{~m})$ and site $2(1940 \mathrm{~m})$ compared to the mooring location. The observed deflection is expected to be greater than the modeled deflection; this may partially explain why the modeled deflection fails to fall within the vicinity of the mapped seep-related seafloor features.

- The SAR acquisition deficiency from the $\mathrm{C}$ and $\mathrm{X}$ band satellite constellation inhibits the spontaneous quantification of the deflection. To improve the accuracy of the method, the integration of a larger SAR dataset (Ku -bands) during mooring records would be instrumental in quantifying the deflection and therefore estimate the ascension velocity through the water column.

\subsection{Modifications parameters of the ascension velocity through the water column}

In this section, we propose possible interactions between bubbles and the environment that could explain the difference between modeling and observations. The bubble ascension velocity was reported to decrease through the water column in the Black Sea (Greinert et al., 2006). The hydrate bubble coating only occur within the Gas Hydrate Stability Zone (GHSZ) and is known to delay the dissolution of light methane, prohibiting the interactions between ocean water and methane (Rehder et al., 2002; McGinnis et al., 2006). In the LCB, hydraterelated BSR that mark the base of the GHSZ was already reported within the sedimentary series (Lucazeau et al., 2004; Zühlsdorff and Spiess, 2005; Gay et al., 2006b). The top of the GHSZ that depends on the seasurface temperature and the thermal gradient is estimated at $430 \mathrm{~m}$ below sea surface (Kvenvolden and Barnard, 1983; Dholabhai et al., 1991; Rehder et al., 2002; McGinnis et al., 2006; Sloan and Koh, 2008). The rapid gas components dissolution above the GHSZ leads to a relative increase in the oil/gas ratio, resulting in a decrease of buoyant forces and ascension velocity through the water column. For seep sites characterized by an oil and gas mixture, $80-99 \%$ of methane dissolves in the water column while rising to the sea surface (Solomon et al., 2009). Even if the effect of a hydrate bubble coating on the ascension velocity remains poorly documented, the methane preservation in stable hydrate conditions presumably steers the ascent regime. In addition, the plume consistency produces an ensemble of buoyancy forces that decrease the transit time to the sea surface in the case of high fluid flow (Leifer et al., 2006). Methane dissolution would therefore produce a dual effect on the ascension velocity by increasing the oil/gas ratio and diminishing the buoyant forces. Moreover, the seawater density gradient of the LCB $\left(\Delta=5 \mathrm{gl}^{-1}\right)$ is high compared to other seeping regions (Greinert et al., 2006) and the associated water layering appears to significantly contribute to the hydrographical dynamics of the
LCB (Fig. 5b). The strong decrease in the seawater density of the upper layer probably also contributes to the decrease in the density contrast between hydrocarbon bubbles and seawater. Experimental studies demonstrated that a consistent portion of crude oil remains potentially stored between layered water mass units (Adalsteinsson et al., 2011; Camassa et al., 2013; Landeau et al., 2014; Mirajkar et al., 2015). Hydrocarbon stratification is possible in the LCB above the GHSZ and may be expected below the shallow and buoyant Congo River Plume waters.

In this study, we approximated the ascension velocity as constant through the water column. However, a decrease in the bubble velocity model, or hydrocarbon stratification in the water column, would relatively enhance the impact of sub-surface currents compared to bottom currents, by increasing the residence time of the oil droplet in the subsurface. Since the sub-surface dynamics flowed north-westward during the acquisition of ALOS SAR scene (Fig. 9), the modeled deflection would best fit between the observed location of seafloor pockmarks and sea surface OSO considering a slower bubble velocity in the subsurface water layer. However, the connection between surface slicks and seafloor pockmarks suggests that the delay associated with a decrease in the ascension velocity cannot be considered as a prevailing contributor to the underwater deflection.

\subsection{Comparison with predicted ascent models}

After listing in the previous section the potential parameters that might modify the rising velocity, we will provide a comparative study of reported ascension velocity values in this section. The model established by Clift et al. (1978) considered a range of probable ascension velocities up to $50 \mathrm{~cm} \mathrm{~s}^{-1}$ for expelled rising hydrocarbon bubbles with ellipsoidal shapes. This study shows that probable ascension velocities of natural oil bubbles range between 3 and $8 \mathrm{~cm} \mathrm{~s}^{-1}$ in the LCB, which would correspond to a range of bubble diameter distribution between 0.3 and $0.8 \mathrm{~mm}$ and a spherical ascension regime (Clift et al., 1978). This corresponds to the lower range of reported values (Leifer and Patro, 2002) but remains consistent with low energy releases. Conversely, only larger methane bubbles $(>2.4 \mathrm{~mm})$ are presumed to reach the sea surface (Solomon et al., 2009). The density of oil naturally entering the environment are largely increased under the action of bacteria either during the migration through the sediments (Head et al., 2003; Larter et al., 2003, 2006; Jones et al., 2008), across the water column (Aeppli et al., 2014) or under water washing processes (Palmer et al., 1993). Oil density modification can potentially results in oil plume drop-off on the seafloor (Valentine et al., 2014). Expelled oils are usually more viscous and heavier than oil found in reservoirs due to severe biodegradation. Therefore, the ascension velocity of natural oil is presumed to be slower than anthropogenic spills and therefore produces larger deflection cut-off values (Fig. 11). This study shows that modeled deflection velocities are not compatible with reported sizes of sea surface bubbles, which suggest that natural oil bubbles probably follow a different regime than the classical "ellipsoidal" regime (Clift et al., 1978). In agreement with nearby acquisitions of photos/videos at seafloor seeps (unpublished data), we believe that the expulsion of oils rather occurs as threadlike oil streaks instead of regular bubbles. The presumed difference in the bubble regime is probably associated with the degree of hydrocarbon biodegradation in the sedimentary series (Wenger and Isaksen, 2002; Head et al., 2003; Larter et al., 2003, 2006; Peters et al., 2007; Jones et al., 2008). Additional information related to hydrocarbon composition would significantly help to constrain the ascension velocity and therefore improve hydrocarbon ascension modeling through the water column. 


\subsection{Horizontal deflection compared to the water depth}

The maximum lateral deflection of oil droplets through the water column is sometimes estimated using linear functions that depend on the water depth (Garcia-Pineda et al., 2010). Deflection laws are probably valid for uniform vertical current components, but this study refutes this assumption for complex hydrodynamic settings. The vertical displacement of oil slicks from the origin on the seafloor can reach a distance up to 5 times the water depth in the Gulf of Mexico (GarciaPineda et al., 2010). In the LCB, the deflection cut-off remains below the value of the water depth for most (95\%) of recurrent seepage sites (deflection range to water depth ratio of less than 1). The deflection cutoff outreaches the water depth only for shallow seepage sites (water depth of $1200 \mathrm{~m}$ ). The hydrodynamic conditions of the LCB are characterized by multiple current components (Fig. 1) and the averaged current distribution shows opposite current directions between water masses (Figs. 5 and 7). The reverse currents relatively decrease the vertical deflection distance between the location of the OSO and its vertical projection on the seafloor (Fig. 9), which explains why the total value of the horizontal deflection remains low compared to the water depth.

The deflections modeled with slow ascension velocities (2 and 2.5) were consistently different from the deflections computed for $3-50 \mathrm{~cm} \mathrm{~s}^{-1}$. The spot intensification of the current speed observed at $969 \mathrm{~m}, 18 \mathrm{~h}$ before the SAR acquisitions induced strong south-west deflection (Fig. 7). This could explain the difference in orientation for backward propagation models at lower ascension velocities. The transit period can be strongly different $(3 \mathrm{~h} 50-25 \mathrm{~h}$ ) depending on the water depth $(1100-2700 \mathrm{~m})$ and ascension velocity $\left(3-8 \mathrm{~cm} \mathrm{~s}^{-1}\right)$. Therefore, it is highly probable that the underwater deflection between shallow $(1100 \mathrm{~m})$ and deeper seep sites $(2700 \mathrm{~m})$ during simultaneous active stages will be consistently different.

Mooring 1 is $430 \mathrm{~m}$ deeper than mooring 2, yet the stack of the theoretical OSO location along the monitoring period shows that modeled OSO spans a larger distance for the shallower mooring 2 (Fig. 11c and d). Proximal areas from the shelf are probably affected by more consistent current variability between the BCC (Hopkins et al., 2013) and the AC (Hardman-Mountford et al., 2003), but also can be affected by a "Venturi effect" that increases the velocity of water masses towards the shelf. The enhancement of the current velocity in shallower areas of the LCB (Santos et al., 2012; Kopte et al., 2017) is probably responsible for the greater deflection values observed during long-term monitoring (Jatiault et al., 2017).

The average location of OSO (modeled GMC; white star in Fig. 11c, d) is horizontally displaced by $350 \mathrm{~m}$ from for the vertical projection of the seafloor origin for mooring 1 while it roughly corresponds to the sub-vertical projection of the seafloor origin for mooring 2. Considering that the recording period of Mooring 1 is restricted to 6 months, the average deflection observed for Mooring 1 (350 m towards the Northwest; Fig. 11c) is presumably associated with seasonal variations in the current direction distribution (Hardman-Mountford et al., 2003; Kopte et al., 2017). This suggests that the sub-vertical link between the GMC location and the seafloor origin is only valid considering a SAR dataset acquired homogeneously throughout the year. The measured deflection distribution is associated with a slighter prominent orientation of the deflection along the slope axis (Fig. 10a) in agreement with modeled deflections (Fig. 11a, b). This suggests that the main current distributions prevail on droplet deflection compared to the water depth in open sea-conditions. The comparison between measured current velocity at a local scale and regional scale models (HYCOM, SAT-OCEAN) could help clarify the velocity range and thereby improve our understanding of rise paths of oil droplets in the water column.

\section{Summary and conclusion}

In this paper, we estimated a range of probable ascension velocities of oil droplets through the water column in the case of natural oil seepage systems. This study brings new insights in understanding the effect of vertical current variations on the oil droplet deflection through the water column and provides a predictive model for the deflection of natural oil droplets in natural seeps. The following conclusions were established from the integration of SAR slicks inventory, mooring measurements, and bathymetric data:

- The bi-decadal SAR monitoring of seepage manifestations shows that the OSO locations are limited to a maximum deflection of $2500 \mathrm{~m}$ in diameter from the seafloor origin.

- The modeled path for oil droplets shows that most of the lateral deflection occurs in the subsurface layer where the current velocity intensifies, and the ascension velocity of the oil droplets decreases.

- The integration of ADCP measurements successfully supports the reverse modeling method looking at the vertical migration of oil droplets from seep-related seafloor features to slicks at the surface while considering a range of ascension velocity through the water column. The best results were obtained based on ascension velocities between $3 \mathrm{~cm} \mathrm{~s}^{-1}$ to $8 \mathrm{~cm} \mathrm{~s}^{-1}$.

- Shallower seepage sites are affected by a greater average deflection value which therefore confirms that affine deflection functions between the deflection value and the water depth are not applicable for complex hydrographical provinces such as open sea conditions.

- For most of the recurrent seep sites, the horizontal deflection of oil droplets remains below the value of the water depth. The reverse currents associated with a vertical hydrographical layering in the LCB decreases the horizontal deflection values of the oil plume.

\section{Acknowledgements}

This study was performed as a part of a PhD project in the framework of a CIFRE contract funded by Total SA and granted by the ANRT (Agence Nationale de la Recherche et de la Technologie), No. 2014/0308. This project is built on collaboration with the University of Perpignan, France. The satellite data were provided by the European Space Agency (Envisat WSM, IMP), Canadian Space Agency (Radarsat), German Aerospace Centre (Terrasar-X), Italian Space Agency (Cosmo-skymed) and Japan Aerospace Exploration Agency (JAXA). We address our sincere gratitude to Total SA for providing the seafloor data and current measurements and for permitting the publication of this study.

\section{Appendix A}

See Figs. A.1 and A.2. 

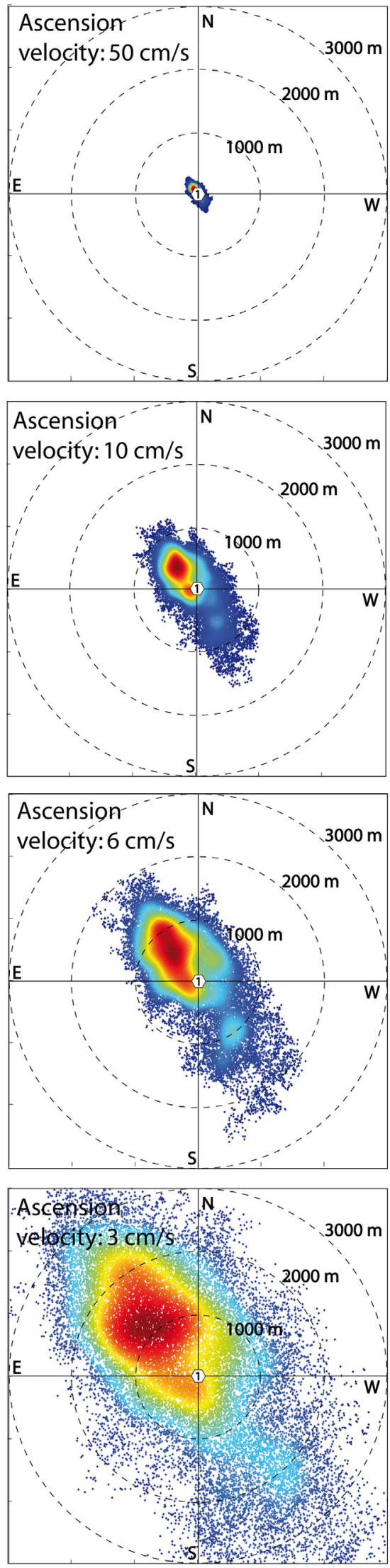
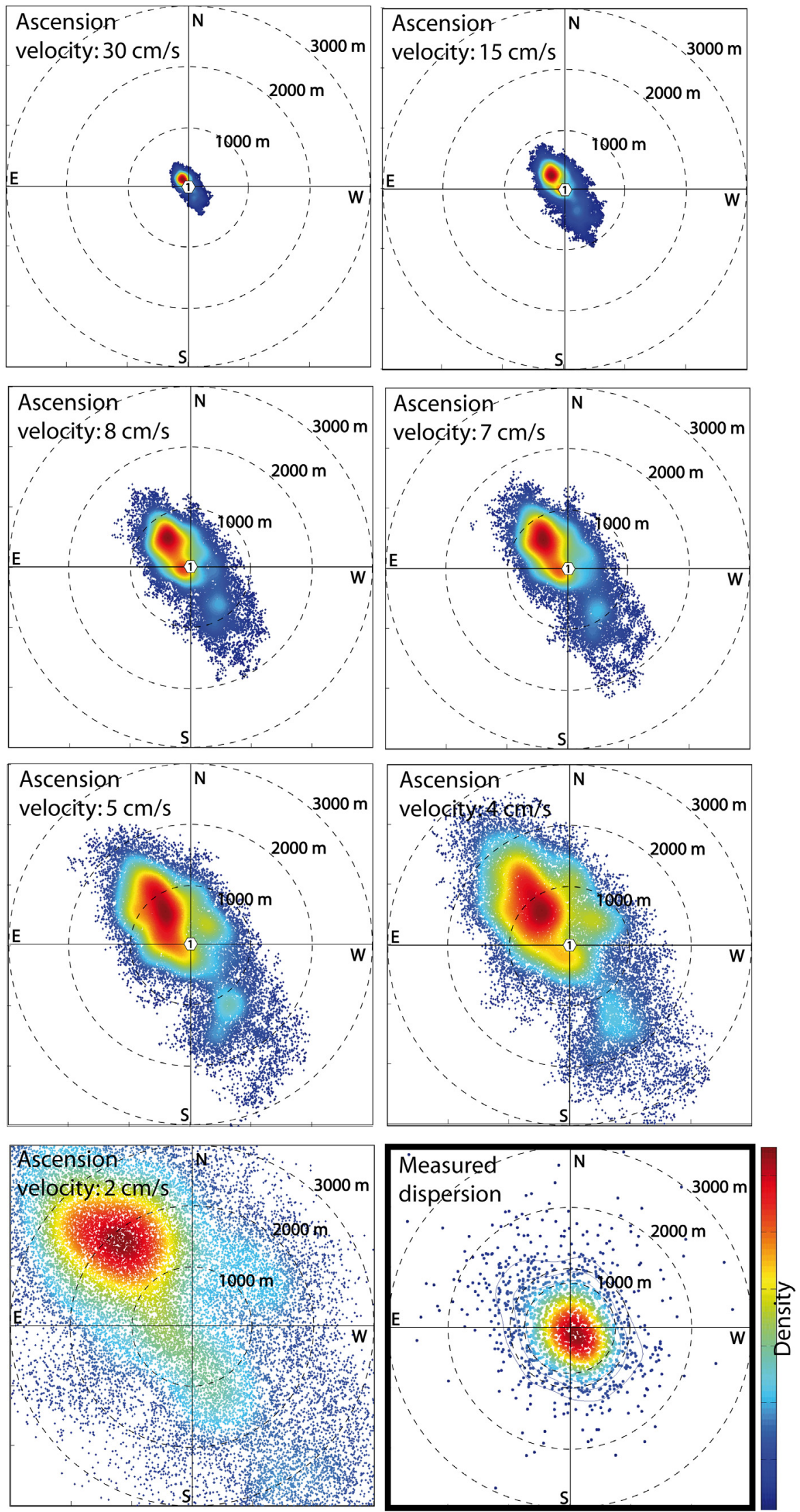

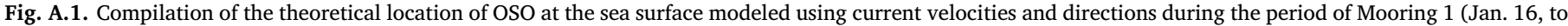

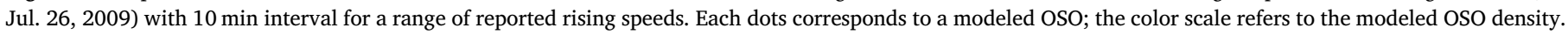
The location of the Mooring 1 corresponds to the location of the modeled origin of the expelled oil plume. Bottom right: Measured deflection distribution. 

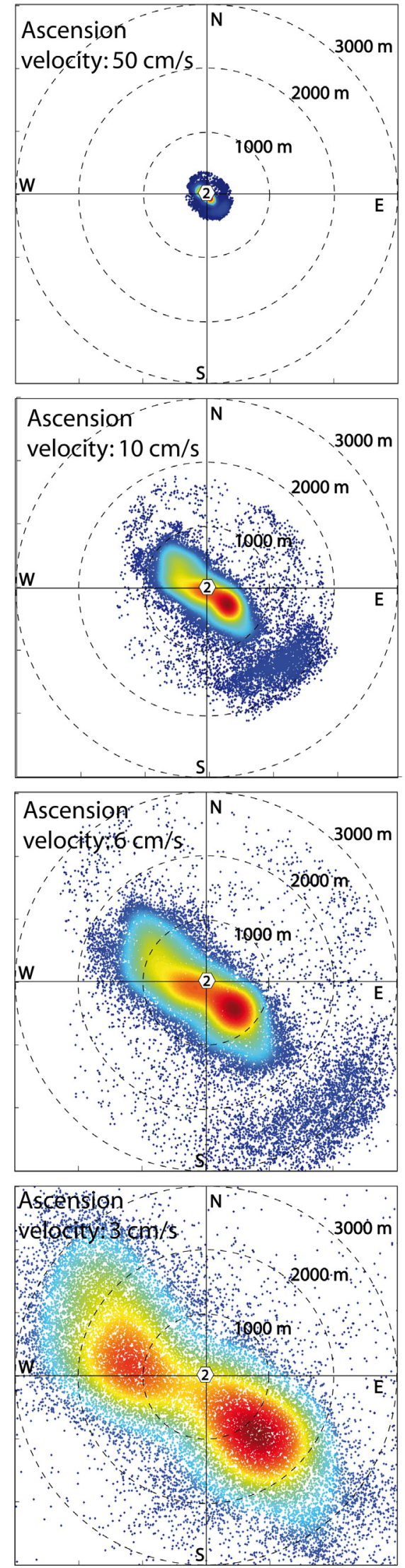
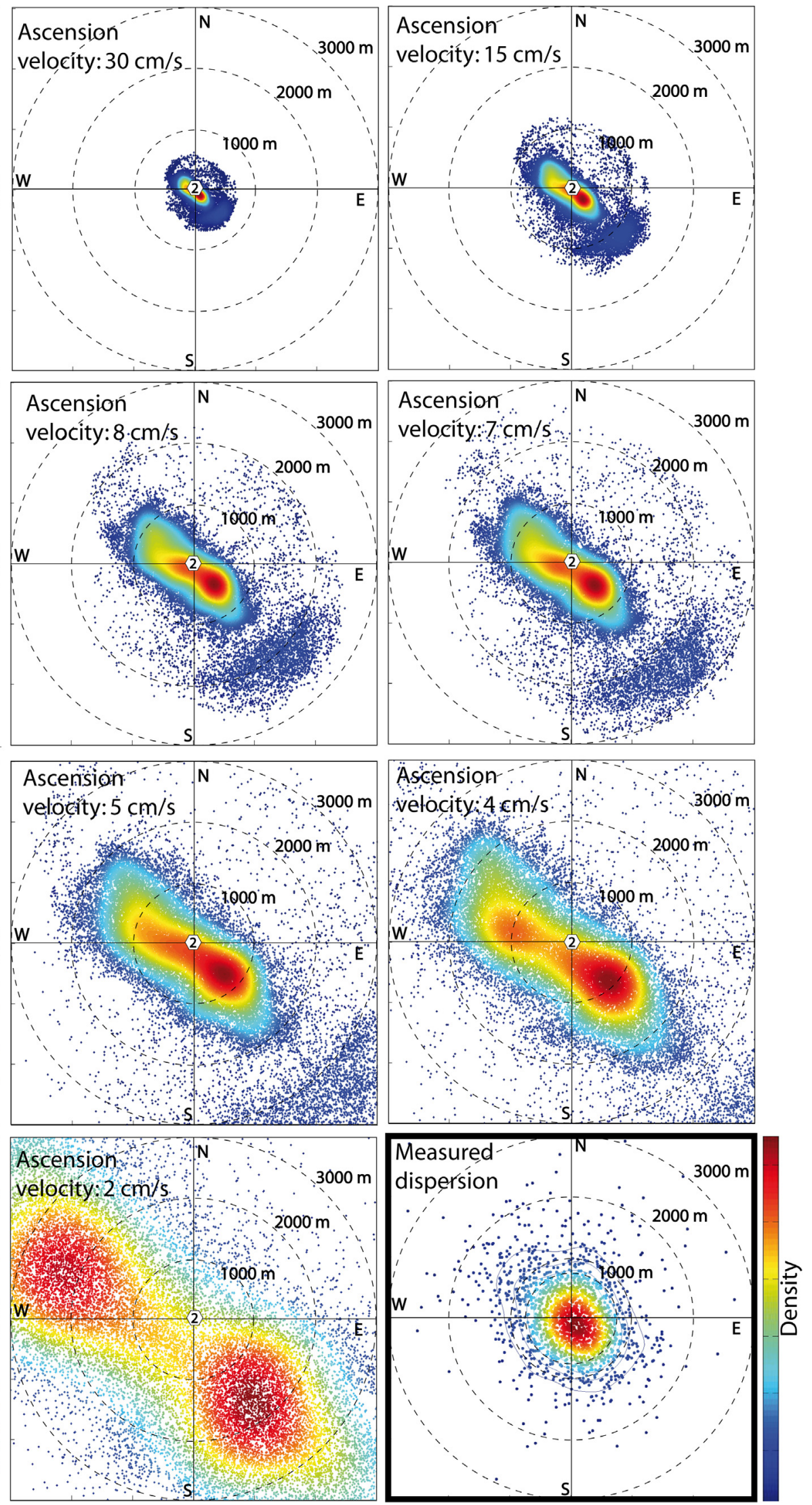

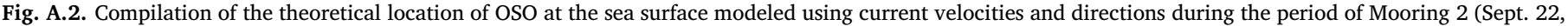

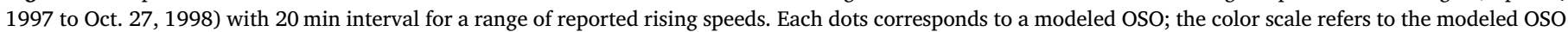

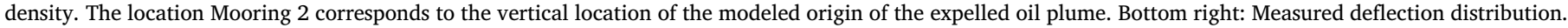




\section{References}

Abrams, M.A., 2005. Significant of hydrocarbon seepage relative to petroleum generation and entrapment. Mar. Pet. Geol. 22, 457-477.

Adalsteinsson, D.D., Camassa, R.R., Harenberg, S.S., Lin, Z.Z., Mclaughlin, R.M., Mertens, K.K., White, B.B., 2011. Subsurface trapping of oil plumes in stratification: laboratory investigations. In: Liu, Yonggang, Macfadyen, Amy, Ji, Zhen-Gang, Weisberg, Robert H. (Eds.), Monitoring and Modeling the Deepwater Horizon Oil Spill: A RecordBreaking Enterprise 1. American Geophysical Union, pp. 257-262.

Aeppli, C., Nelson, R.K., Radovic, J.R., Carmichael, C.A., Valentine, D.L., Reddy, C.M., 2014. Recalcitrance and degradation of petroleum biomarkers upon abiotic and biotic natural weathering of deepwater horizon oil. Environ. Sci. Technol. 48 (12), 6726-6734.

Andresen, K.J., Huuse, M., 2011. 'Bulls-eye' and polygonal faulting in the Lower Congo Basin: relative timing and implications for fluid expulsion during shallow burial. Mar. Geol. 279, 111-127. http://dx.doi.org/10.1016/j.margeo.2010.10.016.

Andresen, K.J., 2012. Fluid flow features in hydrocarbon plumbing systems: what do they tell us about the basin evolution. Mar. Geol. 332-334, 89-108. http://dx.doi.org/10. 1016/j.margeo.2012.07.006.

Aprin, L., Heymesa, F., Laureta, P., Slangena, P., Le Floch, S., 2015. Experimental characterization of the influence of dispersant addition on rising oil droplets in water column. Chem. Eng. 43.

Arhan, M., Mercier, H., Park, Y.H., 2003. On the deep water circulation of the eastern South Atlantic Ocean. Deep Sea Res. Part I: Oceanogr. Res. Pap. 50 (7), 889-916.

Becker, P.R. and Manen, C.A. (1988). Natural Oil Seeps in the Alaskan marine environment. Outer Continental Shelf Environmental Assessment Program Research Unit 703.

Brun, J.P., Fort, X., 2004. Compressional salt tectonics (Angolan Margin). Tectonophysics 382, 129-150. http://dx.doi.org/10.1016/j.tecto.2003.11.014.

Burwood, R., 1999. Angola: source rock control for Lower Congo Coastal and Kwanza Basin petroleum systems 152. Geological Society, London, pp. p181-p184.

Camassa, R., Khatri, S., McLaughlin, R., Mertens, K., Nenon, D., Smith, C., Viotti, C. 2013. Numerical simulations and experimental measurements of dense-core vortex rings in a sharply stratified environment. Comput. Sci. Discov. 6 (1), 014001.

Chen, H., An, W., You, Y., Lei, F., Zhao, Y., Li, J., 2015. Numerical study of underwater fate of oil spilled from deepwater blowout. Ocean Eng. 110, 227-243.

Chen, H.Z., Li, D.M., Xiao, L., 2007. Mathematical modeling of oil spill on the sea and application of the modeling in Daya Bay. J. Hydrodyn., Ser. B 19 (3), 282-291.

Clift, R., Grace, J.R., Weber, M.E., Bubbles, D., 1978. Particles. Academic, New York, pp $171-202$.

Cole, G.A., Requejo, A.G., Ormerod, D., Yu, Z., Clifford, A., 2000. Petroleum geochemical assessment of the Lower Congo Basin. In: Mello, M.R., Katz, B.J. (Eds.), Petroleum Systems of South Atlantic Margins: AAPG Memoir 73. pp. 325-339.

Crooke, E., Talukder, A., Ross, A., Trefry, C., Caruso, M., Carragher, P., Stalvies, C., Armand, S., 2015. Determination of sea-floor seepage locations in the Mississippi Canyon. Mar. Pet. Geol. 59, 129-135. http://dx.doi.org/10.1016/j.marpetgeo.2014. 08.004.

De Beukelear, S.M., MacDonald, I.R., Guinasso, N.L., Murray, J.A., 2003. Distinct sidescan sonar, RADARSAT SAR, and acoustic profiler signatures of gas and oil seeps on the Gulf of Mexico slope. Geo-Mar. Lett. 23, 177-186.

De Moustier, C., Zabal, X., Boelmann, J., Kraft, B.J., Zielinski, O., Fox, P.A., 2013. Nearbottom acoustical detection of bubble streams emanating from natural sea floor seeps in the Gulf of Mexico. In: Proceedings of Offshore Technology Conference (Vol. 24171).

Dholabhai, P.D., Englezos, P., Kalogerakis, N., Bishnoi, P.R., 1991. Equilibrium conditions for methane hydrate formation in aqueous mixed electrolyte solutions. Can. J. Chem. Eng. 69 (3), 800-805.

Espedal, H.A., Johannessen, O.M., 2000. Detection of oil spills near offshore installations using synthetic aperture radar (SAR). Int. J. Remote Sens. 21 (11), 2141-2144. http://dx.doi.org/10.1080/01431160050029468.

Espedal, H.A., Wahl, T., 1999. Satellite SAR oil spill detection using wind history information. Int. J. Remote Sens. 20, 49-65.

Fingas, M., Brown, C., 2014. Review of oil spill remote sensing. Mar. Pollut. Bull. 83 (1), 9-23. http://dx.doi.org/10.1016/j.marpolbul.2014.03.059.

Fort, X., Brun, J.P., Chauvel, F., 2004. Salt tectonics on the Angolan margin, synsedimentary deformation processes. AAPG Bull. 88 (11), 1523-1544.

Gade, M., Alpers, W., 1998. Imaging of biogenic and anthropogenic ocean surface films by the multifrequency/multipolarization SIR-C/X-SAR. J. Geophys. Res. 103, 18851-18866.

Garcia-Pineda, O., MacDonald, I., Silva, M., Shedd, W., Asl, S.D., Schumaker, B., 2015. Transience and persistence of natural hydrocarbon seepage in Mississippi canyon, Gulf of Mexico. Deep Sea Res. Part II: Top. Stud. Oceanogr. 129, 119-129.

Garcia-Pineda, O., MacDonald, I., Zimmer, B., Shedd, B., Roberts, H., 2010. Remotesensing evaluation of geophysical anomaly sites in the outer continental slope, northern Gulf of Mexico. Deep-Sea Res. II 57, 1859-1869. http://dx.doi.org/10. 1016/j.dsr2.2010.05.005.

Garzoli, S.L., Dong, S., Fine, R., Meinen, C.S., Perez, R.C., Schmid, C., Yao, Q., 2015. The fate of the deep western boundary current in the South Atlantic. Deep Sea Res. Part I: Oceanogr. Res. Papers, 103, 125-136.

Gay, A., Lopez, M., Berndt, C., Séranne, M., 2007. Geological controls on focused fluid flow associated with seafloor seeps in the Lower Congo Basin. Mar. Geol. 244, 68-92. http://dx.doi.org/10.1016/j.margeo.2007.06.003.

Gay, A., Lopez, M., Cochonat, P., Levaché, D., Sermondadaz, G., Seranne, M., 2006a. Evidences of early to late fluid migration from an upper Miocene turbiditic cannel revealed by 3D seismic coupled to geochemical sampling within seafloor pockmarks, Lower Congo Basin. Mar. Pet. Geol. 23, 387-399. http://dx.doi.org/10.1016/j. marpetgeo.2006.02.004.

Gay, A., Lopez, M., Cochonat, P., Séranne, M., Levaché, D., Sermondadaz, G., 2006b. Isolated seafloor pockmarks linked to BSRs, fluid chimneys, polygonal faults and stacked Oligocene-Miocene turbiditic paleochannels in the Lower Congo Basin. Mar. Geol. 226, 25-40. http://dx.doi.org/10.1016/j.margeo.2005.09.018.

Gordon, R.L., Instruments, R.D., 1996. Principles of Operation a Practical Primer. RD Instruments, San Diego.

Greinert, J., Artemov, Y., Egorov, V., De Batist, M., McGinnis, D., 2006. 1300-m-high rising bubbles from mud volcanoes at $2080 \mathrm{~m}$ in the Black Sea: hydroacoustic characteristics and temporal variability. Earth Planet. Sci. Lett. 244, 1-15. http://dx.doi. org/10.1016/j.epsl.2006.02.011.

Guiraud, M., Buta-Neto, A., Quesne, D., 2010. Segmentation and differential post-rift uplift at the Angola margin as recorded by the transform-rifted Benguela and obliqueto-orthogonal-rifted Kwanza basins. Mar. Pet. Geol. 27 (5), 1040-1068.

Hardman-Mountford, N.J., Richardson, A.J., Agenbag, J.J., Hagen, E., Nykjaer, L., Shillington, F.A., Villacastin, C., 2003. Ocean climate of the South East Atlantic observed from satellite data and wind models. Progress. Oceanogr. 59, 181-221. http:// dx.doi.org/10.1016/j.pocean.2003.10.001.

Head, I.M., Jones, D.M., Larter, S.R., 2003. Biological activity in the deep subsurface and the origin of heavy oil. Nature 426 (6964), 344-352.

Holmes, M.E., Schneider, R.R., Müller, P.J., 1997. Reconstruction of past nutrient utilization in the eastern Angola Basin based on sedimentary 15N/14N ratio1997. Paleoceanography 12 (4), 604-614.

Hopkins, J., Lucas, M., Dufau, C., Sutton, M., Stum, J., 2013. Detection and variability of the Congo River plume from satellite derived sea surface temperature, salinity, ocean colour and sea level. Remote Sens. Environ. 139, 365-385.

Hovland, M., Judd, A.G., 1988. Seabed pockmarks and seepages: Impact on geology, biology and the marine environment: London. Graham Trotman 293.

Ivanov, A.Y., Gobulov, B.N., Zatyagalova, B.B., 2007. On oil and gas seeps and underground fluid discharges in the Southern Caspian based on space radar data. Earth Explor. Sp. 2, 62-81.

Jatiault, R., Dhont, D., Loncke, L., Dubucq, D., 2017. Monitoring of natural oil seepage in the Lower Congo Basin using SAR observations. Remote Sens. Environ. 191, 258-272. http://dx.doi.org/10.1016/j.rse.2017.01.031.

Jauer, C.D., Budkewitsch, P., 2010. Old marine seismic and new satellite radar data: petroleum exploration of north west Labrador Sea, Canada. Mar. Pet. Geol. 27 (7), 1379-1394. http://dx.doi.org/10.1016/j.marpetgeo. 2010.03.003.

Johannessen, O.M., Sandven, M., Jenkins, A.D., Durand, D., Petterson, L.H., Espedal, H., Evensen, G., Hamre, T., 2000. Satellite earth observation in operational oceanography. Coast. Eng. 41, 155-176.

Johansen, C., Todd, A.C., MacDonald, I.R., 2017. Time series video analysis of bubble release processes at natural hydrocarbon seeps in the northern Gulf of Mexico. Mar. Pet. Geol. 82, 21-34.

Jones, D.M., Head, I.M., Gray, N.D., Adams, J.J., Rowan, A.K., Aitken, C.M., Oldenburg, T., 2008. Crude-oil biodegradation via methanogenesis in subsurface petroleum reservoirs. Nature 451 (7175), 176-180.

Jones, D.O.B., Walls, A., Clare, M., Fiske, M.S., Weiland, R.J., O'Brien, R., Touzel, D.F., 2014. Asphalt mounds and associated biota on the Angolan margin. Deep-Sea Res. I. http://dx.doi.org/10.1016/j.dsr.2014.08.010.

King, L.H., MacLean, B., 1970. Pockmark on the Scotian Shelf. Geol. Soc. Am. Bull. V.81, 3141-3148.

Kopte, R., Brandt, P., Dengler, M., Tchipalanga, P.C.M., Macuéria, M., Ostrowski, M., 2017. The Angola Current: flow and hydrographic characteristics as observed at $11^{\circ} \mathrm{S}$ J. Geophys. Res.: Oceans.

Körber, J.H., Sahling, H., Pape, T., dos Santos Fereira, C., MacDonald, I., Bohrmann, G., 2014. Natural oil seepage at Kobuleti Ridge, eastern Black Sea. Marine and Petroleum Geology 50. pp. 68-82. http://dx.doi.org/10.1016/j.marpetgeo.2013.11.007.

Korotenko, K.A., 2016. High-Resolution Numerical Model for Predicting the Transport and Dispersal of Oil Spill in Result of Accidental Deepwater Blowout in the Black Sea. In: Proceedings of the 26th International Ocean and Polar Engineering Conference. International Society of Offshore and Polar Engineers.

Kvenvolden, K.A., Barnard, L.A., 1983. Hydrates of natural gas in continental margins. Stud. Cont. Margin Geol. 34, 631-640.

Kvenvolden, K.A., Cooper, C.K., 2003. Natural seepage of crude oil into the marine environment. Geo-Mar. Lett. 23, 140-146. http://dx.doi.org/10.1007/s00367-0030135-0.

Landeau, M., Deguen, R., Olson, P., 2014. Experiments on the fragmentation of a buoyant liquid volume in another liquid. J. Fluid Mech. 749, 478-518.

Larter, S., Huang, H., Adams, J., Bennett, B., Jokanola, O., Oldenburg, T., Fowler, M., 2006. The controls on the composition of biodegraded oils in the deep subsurface part II - geological controls on subsurface biodegradation fluxes and constraints on reservoir-fluid property prediction1. AAPG Bull. 90 (6), 921-938.

Larter, S., Wilhelms, A., Head, I., Koopmans, M., Aplin, A., Di Primio, R., Telnaes, N., 2003. The controls on the composition of biodegraded oils in the deep subsurface - part 1: biodegradation rates in petroleum reservoirs. Org. Geochem. 34 (4), 601-613.

Leifer, I., Lehr, W.J., Simecek-Beatty, D., Bradley, E., Clark, R., Dennison, P., Hu, Y., Matheson, S., Jones, C.E., Holt, B., Reif, M., Roberts, D.A., Svejkovsky, J., Swayze, G., Wozencraft, J., 2012. State of the art satellite and airborne marine oil spill remote sensing: application to the BP Deepwater Horizon oil spill. Remote Sens. Environ. 124, 185-209. http://dx.doi.org/10.1016/j.rse.2012.03.024.

Leifer, I., Luyendyk, B.P., Boles, J., Clark, J.F., 2006. Natural marine seepage blowout: contribution to atmospheric methane. Glob. Biogeochem. Cycles 20 (3). 
Leifer, I., MacDonald, I., 2003. Dynamics of the gas flux from shallow gas hydrate deposits: interaction between oily hydrate bubbles and the oceanic environment. Earth Planet. Sci. Lett. 210 (2003), 411-424.

Leifer, I., Patro, R.K., 2002. The bubble mechanism for methane transport from the shallow sea bed to the surface: a review and sensitivity study. Cont. Shelf Res. 22 (16), 2409-2428.

Lessard-Pilon, S., Porter, M.D., Cordes, E.E., MacDonald, I., Fisher, C.R., 2010 Community composition and temporal change at deep Gulf of Mexico cold seeps. Deep Sea Res. Part II: Top. Stud. Oceanogr. 57 (21), 1891-1903.

Levy, E.M., Ehrhardt, M., 1981. Natural seepage of petroleum at Buchan Gulf, Baffin Island. Mar. Chem. 10 (4), 355-364.

Lucazeau, F., Brigaud, F., Bouroullec, J.-L., 2004. High-resolution heat flow density in the lower Congo basin (http://dx.doi.org/). Geochem., Geophys., Geosystems 5. http:// dx.doi.org/10.1029/2003GC000644.

Lynn, R.J., 1971. On potential density in the deep South Atlantic Ocean. J. Mar. Res. 29, 171-177.

MacDonald, I.R., Garcia-Pineda, O., Beet, A., Daneshgar Asl, S., Feng, L., Graettinger, G., French-McCay, D., Holmes, J., Hu, C., Huffer, F., Leifer, I., Muller-Karger, F., Solow, A., Silva, M., Swayze, G., 2015. Natural and unnatural oil slicks in the Gulf of Mexico. J. Geophys. Res.: Oceans 120 (12), 8364-8380.

MacDonald, I.R., Guinasso, N.L., Ackleson, S.G., Amos, J.F., Duckworth, R., Sassen, R., 1993. Natural oil slicks in the Gulf of Mexico visible from space. J. Geophys. Res. 98, 16351-16364.

MacDonald, I.R., Leifer, I., Sassen, R., Stine, P., Mitchell, R., Guinasso, J.N., 2002 Transfer of hydrocarbons from natural seeps to the water column and atmosphere. Geofluids 2, 95-107.

MacDonald, I.R., Reilly Jr., J.F., Best, S.E., Venkataramaiah, R., Sassen, R., Guinasso Jr. N.L., Amos, J., 1996. Remote sensing inventory of active oil seeps and chemosynthetic communities in the northern Gulf of Mexico. In: Schumacher, D., Abrams, M.A. (Eds.), Hydrocarbon Migration and Its Near-surface Expression 66. AAPG Memoir, pp. 27-37.

MacDonald, I.R., Sager, W.W., Peccini, M.B., 2003. Gas hydrate and chemosynthetic biota in mounded bathymetry at mid-slope hydrocarbon seeps: northern Gulf of Mexico. Mar. Geol. 198 (1-2), 133-158.

MacFadyen, A., Watabayashi, G.Y., Barker, C.H., Beegle-Krause, C.J., 2011. Tactical modeling of surface oil transport during the Deepwater Horizon spill response. In: Liu, Yonggang, Macfadyen, Amy, Ji, Zhen-Gang, Weisberg, Robert H. (Eds.), Monitoring and Modeling the Deepwater Horizon Oil Spill: A Record-Breaking Enterprise, pp. 167-178.

MacLean, B., Falconer, R.K.H., Levy, E.M., 1981. Geological, geophysical and chemical evidence for natural seepage of petroleum off the northeast coast of Baffin Island. Bull. Can. Pet. Geol. 29 (1), 75-95.

Marton, G.L., Tari, G.C., Lehmann, C.T., 2000. Evolution of the Angolan passive margin, West Africa, With emphasis on post-salt structural styles. Atl. Rifts Cont. Margins 129-149.

McCandless, S.W., Jackson, C.R., 2003. Principles of synthetic aperture radar. In: Synthetic Aperture Radar Marine User's Manual, pp. 1-24.

McGinnis, D.F., Greinert, J., Artemov, Y., Beaubien, S.E., Wüest, A., 2006. Fate of rising methane bubbles in stratified waters: how much methane reaches the atmosphere? J. Geophys. Res. 11, 1-15. http://dx.doi.org/10.1029/2005JC003183.

Mirajkar, H.N., Tirodkar, S., Balasubramanian, S., 2015. Experimental study on growth and spread of dispersed particle-laden plume in a linearly stratified environment. Environ. Fluid Mech. 15 (6), 1241-1262.

Moroshkin, K.V., Bunov, V.A., Bulatov, R.P., 1970. Water circulation in the eastern South Atlantic Ocean. Oceanology 10, 27-34.

National Research Council Committee on Oil in the Sea, 2003. Oil in the Sea III: Inputs. Fates and Effects. The National Academies Press, Washington, D. C, pp. 280.

Perry, R.H., Green, D.W., 1984. Percy's Chemical Engineers' Handbook, 6th edition. 1984. McGraw Hill Book Co, New York, pp. 2640.

Peters, K.E., Walters, C.C., Moldowan, J.M., 2007. The biomarker guide. Biomark. Isot. Pet. Syst. Earth Hist. 2.

Peterson, R.G., Stramma, L., 1991. Upper-level circulation in the South Atlantic Ocean. Prog. Oceanogr. 26, 1-73.

Phillipson, L., Toumi, R., 2017. Impact of data assimilation on ocean current forecasts in the Angola Basin. Ocean Model. 114, 45-58.

Price, J.M., Reed, M., Howard, M.K., Johnson, W.R., Ji, Z.G., Marshall, C.F., Rainey, G.B., 2006. Preliminary assessment of an oil-spill trajectory model using satellite-tracked, oil-spill-simulating drifters. Environ. Model. Softw. 21 (2), 258-270.
Reed, M., Johansen, Ø., Brandvik, P.J., Daling, P., Lewis, A., Fiocco, R., Prentki, R., 1999. Oil spill modeling towards the close of the 20th century: overview of the state of the art. Spill Sci. Technol. Bull. 5 (1), 3-16.

Rehder, G., Brewer, P.W., Peltzer, E.T., Friederich, G., 2002. Enhanced lifetime of methane bubble streams within the deep ocean. Geophys. Res. Lett. 29 (15), 1731.

Rollet, N., Logan, G.A., Kennard, J.M., O’Brien, P.E., Jones, A.T., Sexton, M., 2006. Characterization and correlation of active hydrocarbon seepage using geophysical data sets: an example from the tropical, carbonate Yampi Shelf, Northwest Australia. Mar. Pet. Geol. 23, 145-164.

Rowe, F., Young, J., 1979. An ocean current profiler using Doppler sonar, Oceans '79 Proceedings.

Santos, F., Gomez-Gesteira, M., Alvarez, I., 2012. Differences in coastal and oceanic SST trends due to the strengthening of coastal upwelling along the Benguela current system. Cont. Shelf Res. 34, 79-86.

Schneider, R.R., Müller, P.J., Ruhland, G., Meinecke, G., Schmidt, H., Wefer, G., 1996. Late Quaternary Surface Temperatures and Productivity in the East-Equatorial South Atlantic: Response to Changes in Trade/ Monsoon Wind Forcing and Surface Water Advection in Wefer, G., Berger, W.H., Siedler, G., Webb, O.J., 1996, The South Atlantic: Present and Past Circulation, 527 - 551.

Schoellkopf, N.B., Patterson, B.A., 2000. Petroleum systems of offshore, Cabinda, Angola, in M. R. Mello and B. J. Katz, Petroleum systems of South Atlantic margins: AAPG Memoir 73, 361-376.

Séranne, M., Anka, Z., 2005. South Atlantic continental margins of Africa: a comparison of the tectonic vs climate interplay on the evolution of equatorial west Africa and SW Africa margins. J. Afr. Earth Sci. 43 (1), 283-300.

Serié, C., Huuse, M., Schødt, N.H., Brooks, J.M., Williams, A., 2016. Subsurface fluid flow in the deep-water Kwanza Basin, offshore Angola. Basin Res.

Shannon., L.V., 2001. Benguela Current, in Ocean Currents: a derivative of encyclopedia of Ocean Sciences, 2nd Edition, p. 23-34.

Sloan, E.D., Koh, C.A., 2008. Clathrate Hydrates of Natural Gases Third Edition. CHEMICAL INDUSTRIES-NEW YORK THEN BOCA RATON-MARCEL DEKKER THEN CRC PRESS-, 119.

Smith, A.J., Flemings, P.B., Fulton, P.M., 2014. Hydrocarbon flux from natural deepwater Gulf of Mexico vents. Earth Planet. Sci. Lett. 395, 241-253.

Spaulding, M.L., 1988. A state-of-the-art review of oil spill trajectory and fate modeling. Oil Chem. Pollut. 4 (1), 39-55.

Solomon, E.A., Kastner, M., MacDonald, I.R., Leifer, I., 2009. Considerable methane fluxes to the atmosphere from hydrocarbon seeps in the Gulf of Mexico. Nat. Geosci. 2 (8), $561-565$.

Stramma, L., England, M., 1999. On the water masses and mean circulation of the South Atlantic Ocean. J. Geophys. Res. 104, 20863-20883.

Stramma, L., Schott, F., 1999. The mean flow field of the tropical Atlantic Ocean. Deep Sea Res. Part II: Top. Stud. Oceanogr. 46 (1), 279-303.

Suresh, G., 2015. Offshore Oil Seepage Visible from Space: a Synthetic Aperture Rada (SAR) based Automatic Detection, Mapping and Quantification System (Doctoral thesis). The University of Bremen, Germany.

Valentine, D.L., Fisher, G.B., Bagby, S.C., Nelson, R.K., Reddy, C.M., Sylva, S.P., Woo, M. A., 2014. Fallout plume of submerged oil from Deepwater Horizon. Proceedings of the National Academy of Sciences, 111(45), 15906-15911.

Van Ganse, S., LeFloch, S., Mauge, R., Aprin, R., 2013. Influence de l'ajout de dispersant sur la remontée de gouttes de pétroles. Apports à la modélisation.

Wenger, L.M., Isaksen, G.H., 2002. Control of hydrocarbon seepage intensity on level of biodegradation in sea bottom sediments. Org. Geochem. 33 (12), 1277-1292.

Williams, A., Lawrence, G., 2002. The Role of Satellite Seep Detection in exploring the South Atlantic's Ultradeep Water, in Surface exploration case histories: Applications of geochemistry, magnetic, and remote sensing, D. Schumacher and L. A.LeSchack, eds., AAPG Studies in Geology No. 48 and SEG Geophysical References Series No. 11, 327-344.

Wilson, R.D., Monaghan, P.H., Osanik, A., Price, L.C., Rogers, M.A., 1973. Estimate of Annual input of Petroleum to the Marine Environment from Natural Marine Seepage. Trans. Gulf Coast Assoc. Geological Societies, 23, 182-193.

Zatyagalova, V.V., Ivanov, A.Y., Gobulov, B.N., 2007. Application of Envisat SAR imagery for mapping and estimation of natural oil seeps in the South Caspian Sea. In Proceedings of the Envisat Symposium 2007, 23 - 27.

Zühlsdorff, L., Spiess, V., 2005. Three-dimensional seismic and acoustic imaging of gas migration and gas hydrate accumulation beneath pockmarks in hemipelagic sediments off Congo, South-west Africa. In: Proceedings of International Conference on Gas Hydrates, Trondheim, Norway (Vol. 5). 